\title{
LA EVOLUCIÓN POLÍTICO-INSTITUCIONAL DE VENEZUELA 1975-2005'
}

\section{The political-institutional evolution of Venezuela 1975-2005}

\author{
Carlos Ayala Corao \\ Profesor Derecho Constitucional \\ Universidad Central y Católica Andrés Bello \\ de Venezuela / cayala@glegal.net \\ Jesús M. Casal \\ Doctor en Derecho. \\ Decano de la Facultad de Derecho \\ de la Universidad Católica Andres Bello \\ de Venezuela / jcasal@ucab.edu.ve
}

RESUM EN: Del mismo modo que ha ocurrido en otros países de América Latina, Venezuela ha experimentado un convulsionado proceso de reforma institucional y constitucional en las últimas décadas. En este trabajo se analizan los aspectos relacionados con el sistema de gobierno, el poder judicial, los derechos fundamentales y los partidos políticos en Venezuela. Este trabajo intenta extraer algunas enseñanzas y también algunos desafios que presenta esta evolución política de Venezuela, sobre todo, examinando la propuesta de reforma constitucional de 2007.

A BSTRA CT: As it has happened in some other countries in Latin A merica, Venezuela has experienced a delicate process of constitutional and institutional reforms over the last decades. In this paper, there are analyzed aspects related to the government system, the judiciary, human rights, and the political parties in Venezuela. This paper pretends to come up with some lessons learnt as well as some challenges wich are intoduced to by this political evolution in Venezuela, mainly tought the examination of the 2007 constitutional reform project.

PALABRAS CLAVE: Derecho constitucional. Estado de derecho. Sistema político.

KEY WO RDS: Constitutional law. Rule of law. Political system.

1 Artículo presentado el 26 de septiembre de 2008. A probado el 22 de octubre de 2008. 


\section{INTRODUCCIÓN}

La evolución político institucional de Venezuela durante el período 1975-2005, estuvo caracterizada por el desarrollo de la Constitución de 1961, luego por una profunda crisis política que llevó a la convocatoria de una A samblea Nacional Constituyente en el año 1999 la cual aprobó una nueva Constitución ese mismo año; y de allí en adelante con la continuación de una crisis política y el desarrollo de un modelo constitucional de democracia "popular" (opuesta a la democracia representativa) con características personalistas, caudillescas y por tanto autoritarias.

La Constitución de 1961 había sido puesta a prueba en los años sesenta por una serie de alzamientos militares y ataques de movimientos guerrilleros, que llevaron a la suspensión y restricción de garantías constitucionales.

Durante el período del presente informe, se llevaron a cabo dos acontecimientos que impactaron fuertemente el sistema constitucional y la democracia misma: el primero, el llamado "Caracazo" durante los días 27 al 29 de febrero de 1989 (a escasos 15 días de la toma de posesión del Presidente Carlos Andrés Pérez), en el cual se presentaron una serie de manifestaciones, disturbios y saqueos masivos en el área metropolitana de Caracas y luego en el resto del país, que dio lugar a una represión con el uso desproporcionado de la fuerza con saldos de ejecuciones extrajudiciales y desapariciones forzadas, en violación de la Constitución y del decreto de suspensión de garantías constitucionales, así como de los tratados relativos a derechos humanos. Y el segundo, dos golpes de estado intentados en el año 1992, uno el 4 de febrero y el otro el 27 de noviembre, los cuales fracasaron.

Si bien la revuelta social de 1989 fue controlada y ambos golpes fracasaron, ello dejó una herida mortal a la presidencia de Carlos Andrés Pérez, quien en gran parte por la presión popular tuvo que salir -como veremos- en virtud de su enjuiciamiento que era la única vía expresamente prevista en la Constitución de 1961. Ello sin embargo, denotaba una crisis más profunda, que iba más allá de la presidencia de la república y llegaba al modelo político, social y económico, es decir, a la democracia misma.

Frente a esta crisis constitucional, en el mismo año 1992, se presentaron dos iniciativas de cambios constitucionales importantes: la primera, la propuesta de Reforma General de la Constitución de 1961 por una Comisión Bicameral del Congreso de la República, nombrada desde 1989 y presidida por el ex Presidente y Senador vitalicio Rafael Caldera. Y la segunda, la activación de un Consejo Consultivo de la Presidencia de la República, presidido por una serie de personalidades y representantes del mundo político, social y económico, el cual planteó entre otras salidas a la crisis, la convocatoria a una Asamblea Nacional Constituyente. Ninguna de las dos iniciativas fue aprobada en los años siguientes, lo cual contribuyó a alimentar el desencanto popular.

En 1998 resultó electo Presidente de la República el líder militar del golpe de estado del 4 de febrero de 1992: el Teniente Coronel del Ejército Hugo Chávez Frías, quien había sido "perdonado" mediante un sobreseimiento del juicio militar decretado por el Presidente Rafael Caldera en el año 1995. Una vez que tomó posesión el Presidente Chávez, activó el mecanismo constituyente. 
Es importante reseñar que de los veintiséis textos constitucionales que ha tenido Venezuela desde 1811, la Constitución de 1961 ha sido la que más ha durado. Permitió el desarrollo de una república civil con una democracia representativa y un sistema de partidos fuertes, el crecimiento económico y la distribución en los años sesenta y principios de los setenta, y la posterior evolución de la descentralización política en los estados y municipios; pero al mismo tiempo que el sistema político permitió engendrar una serie de males no corregidos que toleraron la corrupción y a partir de los años ochenta una peligrosa acumulación de la deuda social y el cambio político.

La experiencia del proceso constituyente y constitucional venezolano vivido desde 1999 hasta la fecha es digna de un estudio, por las repercusiones que el mismo ha tenido en nuestra democracia y nuestro Estado Social de Derecho.

La Constitución de 1961 disponía los mecanismos para su enmienda o reforma, teniendo este último como resultado, luego del referendo popular, la aprobación de una "nueva" Constitución. ${ }^{2}$ No obstante ello, sin haberse modificado previamente la Constitución de 1961, el Presidente de la República el mismo día de su toma de posesión (2-2-1999), dictó un decreto mediante el cual convocó a un referendo "consultivo" para preguntarle al pueblo electoral si éste aprobaba la convocatoria a una A samblea Nacional Constituyente (ANC). ${ }^{3}$ Conforme al decreto presidencial, la segunda pregunta del referendo contenía un inaceptable "plebiscito" mediante el cual se pretendía que el pueblo simplemente le delegare al Presidente el establecimiento de las "bases del proceso comicial en el cual se elegirían los integrantes de la Asamblea Nacional Constituyente". ${ }^{4}$ Una vez enviado el decreto presidencial con la solicitud correspondiente al Consejo Nacional Electoral (CNE), éste decidió en fecha 17 de febrero de 1999, convocar para el día 25 de abril de ese año a un referéndum para que el pueblo se pronuncie sobre la convocatoria a una ANC, de conformidad con dicho decreto presidencial. ${ }^{5}$ Esta convocatoria fue impugnada mediante diversas acciones populares de inconstitucionalidad e ilegalidad ante la Corte Suprema de Justicia, la cual, mediante sentencia de su Sala Político Administrativa de fecha 18-3-99, anuló la segunda pregunta de la convocatoria al referéndum y le ordenó al CNE reformularla,

2 Artículos 245 a 249, Constitución de la República de Venezuela de 1961. El artículo 250 incluso disponía, que dicha Constitución "no perderá su vigencia si dejare de observarse por acto de fuerza o fuere derogada por cualquier otro medio distinto del que ella misma dispone".

3 Pocos días antes de la toma de posesión del nuevo Presidente de la República, la Sala Político Administrativa de la Corte Suprema de Justicia mediante sentencia de fecha 14-1-99 había habilitado implícitamente esta vía, mediante la decisión de un recurso de interpretación legal sobre el alcance del referendo consultivo previsto en la Ley Orgánica del Sufragio y Participación Política.

4 Decreto № 3 de fecha 02-02-99 (Gaceta Oficial № 36.634 de fecha 02-02-99):

Artículo 3. El instrumento electoral contendrá las siguientes preguntas que serán contestadas con un "sí" o con un "no":

Primera: ¿Convoca usted a una Asamblea Nacional Constituyente con el propósito de transformar el Estado y crear un nuevo ordenamiento jurídico que permita el funcionamiento efectivo de una Democracia Social y Participativa?

Segunda: ¿Autoriza usted al Presidente de la República para que mediante un Acto de Gobierno fije, oída la opinión de los sectores políticos, sociales y económicos, las bases del proceso comicial en el cual se elegirán los integrantes de la A samblea Nacional Constituyente?

5 Resolución № 990217-32 dictada por el Consejo Nacional Electoral de fecha 17-2-99. 
examinando las bases que ya habían sido publicadas en el diario oficial como "Propuesta del Ejecutivo Nacional", ${ }^{6}$ y así decidir sobre su incorporación.

Se trataba en definitiva del inicio de un debate cuyo objeto era definir si la Constituyente estaba por encima o al margen de la Constitución de 1961 y por tanto podía establecer un "gobierno constituyente" sin respetar la Constitución, capaz de derogarla parcial o totalmente aun antes de aprobarse la nueva Constitución; o si por el contrario, la Constituyente tenía por objeto elaborar una nueva Constitución y mientras ésta no fuese aprobada, seguía en plena vigencia la Constitución de 1961.

De allí en adelante este debate político-jurídico va a pretender ser zanjado por las decisiones de la Corte Suprema de Justicia (CSJ), pero como veremos, una vez que se instaló la ANC, desconoció estas decisiones judiciales anteriores y comenzó a actuar como una Constituyente con plenos poderes, aun por encima de la Constitución de 1961. Ello nos refiere a la discusión de la teoría constitucional, sobre la constituyente como poder originario sin límites frente a la constituyente como poder popular derivado y limitado.

En este sentido, la Sala Político Administrativa de la CSJ dictó en fecha 23-3-99 una sentencia aclaratoria de su fallo anterior de fecha 10-3-99, mediante el cual, en relación con la primera pregunta del referéndum, ${ }^{7}$ determinó como interpretación vinculante, que en todo caso la ANC, por estar "vinculada al espíritu de la Constitución vigente, está limitada por los principios fundamentales del Estado Democrático de Derecho". Si bien el CNE adoptó una nueva resolución de convocatoria a la $\mathrm{ANC}^{8}$ publicando e incorporando las "Bases Comiciales para el referéndum consultivo sobre la convocatoria de la A samblea Nacional Constituyente a celebrarse el 25 de abril de 1999", en la Base O ctava se hacía mención -entre líneas- a que la ANC se instalaría "como poder originario" que recoge la soberanía popular. En virtud de ello, la Corte Suprema de Justicia en ejecución de la sentencia de 18-3-99 y su aclaratoria de 23-3-99, dictó un nuevo fallo en el cual determinó que dicha calificación de la futura ANC como "poder originario" no sólo estaba "en franca contradicción con los principios y criterios" de estas sentencias, sino que inducía "a error al electorado y a los propios integrantes de la A samblea Nacional Constituyente, si el Soberano se manifestase afirmativamente acerca de su celebración, en lo atinente a su alcance y límites", en virtud de lo cual, dicho Alto Tribunal resolvió reformular la Base Comicial Octava a fin de eliminar esta mención; y ordenó al CNE divulgar suficientemente su nuevo contenido modificado.

Finalmente, el 25 de abril de 1999 se celebró el referéndum y a pesar de una gran abstención, resultó aprobada la convocatoria a la ANC conforme a las Bases Comiciales reformuladas, ${ }^{9}$ y la elección de diputados se celebró el 25-7-99. La ANC se instaló

\footnotetext{
6 "Propuesta del Ejecutivo Nacional que fija la convocatoria de la Asamblea Nacional Constituyente", publicada en la Gaceta Oficial № 36.658 de fecha 10-3-99.

7 Ver supra, cita № 3.

8 Resolución № 990323-71 de fecha 23-3-99.

9 Por la Pregunta № 1, con una participación del 37,65\% del electorado y una abstención del 62,35\%, hubo un total de 3.630.666 votos por el sí (87,75\%). Por la Pregunta № 2, con una participación del 37,65\% del electorado y una abstención del $62,35 \%$, hubo un total de 3.382 .075 votos por el sí $(81,74 \%$ ).
} 
el 8 de agosto de 1999 y de inmediato se afirmó como un "poder originario", en abierto desacato a las decisiones judiciales de la CSJ y a las condiciones (bases) con las cuales se manifestó el pueblo en el referendo sobre su convocatoria. ${ }^{10}$

De allí en adelante, la ANC además de dedicarse a elaborar la nueva Constitución, comenzó en paralelo a actuar como un poder por encima de la Constitución de 1961, llevando a cabo actos de gobierno constituyente contrarios a la Constitución y que incluso la fueron derogando parcial y progresivamente, aun antes de aprobarse la nueva Constitución. ${ }^{11}$ De esta manera, nos quedamos sin "norma suprema" objetiva y ésta pasó a ser lo que la ANC dijera para cada caso en cada decisión que iba tomando. Ello, a pesar de la afirmación contenida en la Base Octava sobre los límites expresos impuestos a la ANC: "Ios valores y principios de nuestra historia republicana, así como el cumplimiento de los tratados internacionales, acuerdos y compromisos válidamente suscritos por la República, el carácter progresivo de los derechos fundamentales del hombre y las garantías democráticas dentro del más absoluto respeto de los compromisos asumidos".

Sin embargo, con posterioridad, una vez instalada la ANC no fue posible hacer efectivos estos límites. En efecto, la ANC comenzó a actuar como un poder originario sin límites, dictando entre otros, los siguientes actos constituyentes contrarios a la Constitución de 1961 pero que en definitiva la iban dejando sin efecto:

1. El Decreto de Reorganización de los órganos del Poder Público.

2. El Decreto de Reorganización del Poder Judicial.

3. El Decreto sobre la Regulación de las Funciones del Poder Legislativo; y el Decreto de reforma parcial del Decreto sobre la Regulación de las Funciones del Poder Legislativo.

4. El Decreto sobre el Régimen de Transición del Poder Público.

Por último, el 17 de diciembre de 1999 la ANC sancionó el texto de la nueva Constitución, la cual fue sometida a referendo popular el 15 de diciembre de ese mismo año

10 Gaceta Oficial № 36.786 del 14 de septiembre de 1999. En efecto, al aprobar el Estatuto de su Funcionamiento la ANC dispuso en su artículo 1 con relación a su naturaleza y misión, lo siguiente:

La Asamblea Nacional es la depositaria de la voluntad popular y expresión de su soberanía con las atribuciones del poder originario para reorganizar el Estado Venezolano y crear un nuevo ordenamiento jurídico democrático. La A samblea, en uso de las atribuciones que le son inherentes, podrá limitar o decidir la cesación de las actividades de las autoridades que conforman el Poder Publico.

Su objetivo será transformar el Estado y crear un nuevo ordenamiento jurídico que garantice la existencia efectiva de la democracia social y participativa.

Parágrafo Primero: Todos los organismos del Poder Público quedan subordinados a la Asamblea Nacional, y están en la obligación de cumplir y hacer cumplir los actos jurídicos estatales que emita dicha Asamblea.

Parágrafo Segundo: La Constitución de 1961 y el resto del ordenamiento jurídico imperante, mantendrán su vigencia en todo aquello que no colida o sea contradictorio con los actos jurídicos y demás decisiones de la Asamblea Nacional. (Resaltados añadidos).

11 Sobre las propuestas de estos actos constituyentes dictados por la ANC y el debate originado en la ANC, ver Brewer-Carías, Allan, Debate Constituyente (A portes a la A samblea Nacional Constituyente), Tomos I, II y III, Editorial Jurídica Venezolana, Caracas, 1999. 
resultando aprobada y luego proclamada por la ANC el 20 del mismo mes y año, y finalmente apareció publicada en la Gaceta Oficial de 30 de diciembre de $1999 .{ }^{12}$ No obstante, de manera inesperada y fuera del debate público, el 24 de marzo de 2001, ya incluso terminadas las sesiones de la ANC, apareció publicada una nueva versión de la Constitución en la Gaceta O ficial13 en la cual supuestamente se "corrigieron" "errores de gramática, sintaxis y estilo" del texto anteriormente publicado oficialmente. ${ }^{14}$

La crisis política venezolana de los años noventa continuó nuevamente desarrollándose en los años dos mil, al punto de que las movilizaciones y manifestaciones políticas de oposición y del gobierno llegaron a su clímax el 11 de abril de 2002 con ocasión de una marcha al palacio Presidencial de Miraflores que terminó con aproximadamente 20 muertos y casi un centenar de heridos. El Alto Mando de la Fuerza Armada Nacional declaró que le había solicitado la renuncia al Presidente Chávez y luego éste fue detenido en instalaciones militares. El 12 de abril se llevó a cabo ese golpe de estado que incluyó la lectura y firma de un decreto de facto que suprimía los poderes públicos. El 13 de abril regresó el Presidente Chávez a sus funciones. No obstante, el clima de violencia y de crisis ha continuado.

Durante los años transcurridos desde el 2000, Venezuela se ha caracterizado institucionalmente por la inexistencia de separación de poderes, la falta de independencia del poder judicial, el grave aumento de la inseguridad personal, los ataques serios a la libertad de expresión (incluidos ataques y agresiones a periodistas, cierre de una de las estaciones de televisión independiente más importantes, leyes, y sentencias restrictivas), amenazas y ataques a defensores de derechos humanos y a la sociedad civil, entre otras. ${ }^{15}$

En el año 2007, el Presidente Chávez una vez reelecto, propuso una "reforma constitucional" que en violación a los límites del poder de reforma establecidos expresamente en la Constitución de 1999, establecía fundamentalmente la reelección indefinida del Presidente de la República, el aumento del período de su mandato, el aumento significativo de los poderes residenciales, la centralización del Estado, la adopción de un Estado socialista y una democracia socialista, y la restricción y disminución de una serie de derechos fundamentales así como el desmontaje de los controles y límites a los estados de excepción. Dicha reforma aprobada por la A samblea Nacional el 2 de noviembre 2007 fue sometida a referendo el 2 de diciembre de ese año, resultando derrotada a pesar del abierto ventajismo oficial. Sin embargo, hasta el día de hoy el Consejo Nacional Electoral no ha proclamado los resultados oficiales.

2 № 36.860.

13 № 5.453 extraordinaria.

14 Un estudio detallado de estos más de doscientos (200) cambios a la Constitución, puede verse en: Brewer-Carías, Allan, La Constitución de 1999. Derecho Constitucional Venezolano. Tomos I y II. Caracas, 2004.

15 Ver, entre otros, los informes sobre Venezuela de la Comisión Interamericana de Derechos Humanos (CIDH) desde el año 2003 (www.cidh.org), los informes anuales del Relator de la ONU sobre la independencia de los Jueces y A bogados (www.unhrhc.orh), Human Rights Watch (www.hrw.org), Comisión Internacional de Juristas (www.icj.org), Internacional Bar Association, informes anuales de ongs venezolanas como Provea (www.provea.org), y Espacio Público (www.espaciopublico.org), entre otros. 


\section{EL SISTEMA DE GOBIERNO}

\section{A. El sistema presidencial}

a. La Constitución de 1961 y las Enmiendas. Durante el período 1975-2005 continuó desarrollándose el sistema de gobierno presidencial sui generis, regulado en la Constitución de 1961 y su Enmienda № 2; y como se verá más adelante, a partir de 1999 por la nueva Constitución. Bajo este sistema, el Presidente de la República es el jefe del Estado y el jefe del Ejecutivo Nacional. ${ }^{16}$ La elección del Presidente se efectuaba por votación universal y directa, resultando electo el candidato que obtenga la mayoría relativa de votos. ${ }^{17}$ El período presidencial al igual que el período constitucional de todos los órganos electos del Poder Nacional duraba cinco (5) años. ${ }^{18}$ La Constitución de 1961 prohibía la reelección del Presidente de la República (que había ejercido por un período constitucional o por más de la mitad del mismo); pero permitía su nueva elección luego de pasados diez (10) años (dos períodos) desde la terminación de su mandato. ${ }^{19}$

Los requisitos constitucionales para ser electo Presidente eran inicialmente ser venezolano por nacimiento, mayor de treinta años y de estado seglar. A partir de 1973, la Enmienda № 1 a la Constitución, añadió como requisito para ser elegido a altos cargos, incluido el de Presidente de la República, el no haber sido condenado, mediante sentencia definitivamente firme, a pena de presidio o prisión superior a tres años, por delitos cometidos en el desempeño de funciones públicas o con ocasión de éstas. ${ }^{20}$

Como régimen presidencial, el mandato del Presidente de la República estaba sujeto a término determinado ( 5 años) y fijo, por lo que en principio, no podía terminar antes de su expiración. ${ }^{21}$ Sin embargo, la Constitución autorizaba el enjuiciamiento (penal) del Presidente, con la autorización del Senado (por el voto de la mayoría de sus miembros) previa declaratoria de la Corte Suprema de Justicia en Pleno de que había méritos para ello. En ese caso, autorizado el enjuiciamiento, el Presidente de la Repú-

Art. 181, Constitución de 1961.

17 Art. 183, Constitución de 1961.

18 Art. 135, Constitución de 1961.

19 Art. 185, Constitución de 1961.

20 Art. 1, Enmienda №1 de la Constitución de 1961, promulgada el 11 de mayo de 1973, Gaceta Oficial № 1.585 de 11-5-73.

21 El mandato del Presidente Luis Herrera Campins fue recortado en aproximadamente 30 días en virtud de la Enmienda № 2 a la Constitución de 1961, en virtud de que ésta adelantó el comienzo de las sesiones del Congreso del día 2 de marzo (art. 154, Constitución de 1961) al día 23 de enero (art. 3, Enmienda № 2). El Presidente electo tomaba posesión del cargo, por disposición constitucional, mediante juramento ante el Congreso "dentro de los diez primeros días de aquél en que deben instalarse en sus sesiones ordinarias del año en que comience el período constitucional" (art. 186, Constitución de 1961). Dicha situación fue decidida en la propia Enmienda № 2, la cual en su Disposición Transitoria estableció que en el período constitucional 1979-1984, la duración del mandato del Presidente de la República (y de los senadores y diputados), se acortaría en los días que resultaran de la aplicación de esa nueva norma. Igualmente la Enmienda dejó en claro, que a los fines de la posible nueva elección de un ex presidente de la República, el plazo de diez años se reduciría de los días que resulten de la aplicación de esa disposición (art. 8). 
blica quedaba suspendido en el ejercicio de sus funciones. ${ }^{22}$ El juicio al Presidente se llevaba a cabo ante la Corte Suprema de Justicia en Pleno. ${ }^{23}$ Como se verá infra, estas normas fueron aplicadas con ocasión del enjuiciamiento del Presidente Carlos Andrés Pérez en el año 1993.

Por otro lado, como se verá infra, conforme a la Constitución de 1961 varias de las facultades del Presidente de la República, estaban sujetas a controles parlamentarios; y a su vez, el Presidente gozaba de facultades tanto legislativas, en especial para dictar decretos leyes, como de veto legislativo. Todos los presidentes, excepto Luis Herrera Campins, hicieron uso de la facultad constitucional para dictar decretos leyes en materia económica, en virtud de la autorización dada en cada caso por el Congreso mediante leyes habilitantes.

Con base en las disposiciones de la Constitución de 1961, en el período entre 1975 y 2005, se celebraron elecciones presidenciales en las cuales resultaron electos (en 1973) Carlos A ndrés Pérez, para el perío do 1974-1979; Luis Herrera Campins, para el período 1979-1984; Jaime Lusinchi para el período 1984-1989; nuevamente Carlos Andrés Pérez para el período 1989-1994; nuevamente Rafael Caldera para el período 1994-1999; y Hugo Chávez para el período 1999-2004.

En primer lugar es importante resaltar, que en este período se llevó a cabo por primera vez la nueva elección de un ex Presidente de la República: Carlos Andrés Pérez (1989-1994) y Rafael Caldera (1994-1999), quienes ya habían sido electos Presidentes para los períodos 1974-1979 y 1969-1974, respectivamente.

En segundo lugar, que por primera vez se llevó a cabo el enjuiciamiento constitucional de un Presidente de la República. ${ }^{24}$ En efecto, Carlos A ndrés Pérez, quien había sido electo por segunda vez como Presidente para el perío do 1989-1994, fue enjuiciado en 1993: la acusación del Fiscal General de la República dio lugar a que la Corte Suprema de Justicia declarara con lugar el antejuicio de mérito el día 20 de mayo de 1993 y el Senado autorizó dicho enjuiciamiento y por tanto suspendió al Presidente Pérez de su cargo el 21 de mayo, luego en agosto de ese mismo año destituido del cargo por decisión del Congreso de la República. ${ }^{25}$ Para cubrir primero la falta temporal y luego la falta absoluta del Presidente Pérez, el Congreso en sesión conjunta de sus cámaras, mediante votación secreta celebrada el día 4 de junio de 1993, eligió como presidente temporal y luego como nuevo Presidente de la República por el resto del período constitucional, el senador Ramón J. Velásquez. ${ }^{26} \mathrm{M}$ ientras esta elección parlamentaria tuvo lugar, se encargó por breve lapso entre el 21 de mayo y el 4 de junio de ese año al entonces Presidente del Congreso, Octavio Lepage. ${ }^{27}$

\footnotetext{
22 Art. 150, ordinal 8ㅇ, Constitución de 1961.

23 Art. 215, ordinal 10, Constitución de 1961.

24 Para un estudio más detallado del enjuiciamiento del Presidente Carlos Andrés Pérez, ver el trabajo de: Ayala Corao, Carlos, "Presentación" en Reformas al Presidencialismo en América Latina, (Linz, Juan; Nohlen, Dieter; Sagües, Néstor; Nogueira, Humberto; A yala Corao, Carlos y Eguiguren, Francisco), Comisión Andina de Juristas y Editorial Jurídica Venezolana, Caracas, 1983.

25 Art. 188, Constitución de 1961.

26 Art. 187, Constitución de 1961.

27 Art. 187, Constitución de 1961.
} 
En tercer lugar, como fue dicho antes en la introducción, durante el período del presente informe, se llevaron a cabo dos acontecimientos que impactaron fuertemente el sistema presidencial y la democracia misma: el primero, el llamado "Caracazo" durante los días 27 al 29 de febrero de 1989; y segundo, los dos golpes de estado que se intentaron en el año 1992, uno el 4 de febrero y el otro el 27 de noviembre. A mbos acontecimientos dejaron una herida mortal a la presidencia de Carlos Andrés Pérez, quien tuvo que salir -como vimos- en virtud de su enjuiciamiento que era la única vía expresamente prevista en la Constitución de 1961.

b. La Constitución de 1999. La Constitución de 1999 introdujo una serie de cambios en relación con el período constitucional, los requisitos, la elección y la reelección presidencial.

En efecto, la Constitución de 1999 estableció una forma de gobierno presidencial, en la cual el Presidente es electo por la mayoría de votos por un período de seis (6) años, pudiendo ser reelecto de inmediato y por una sola vez, para un nuevo período. ${ }^{28} \mathrm{Sin}$ embargo, antes de expirar su período, el mandato del Presidente (así como al resto de los funcionarios electos), puede ser terminado anticipadamente mediante la revocatoria popular de su mandato (referendo revocatorio) (art. 72). La Constitución creó el cargo del Vicepresidente Ejecutivo, como el órgano directo y colaborador del Presidente de la República en su condición de jefe del Ejecutivo nacional, asignándole directamente una serie de facultades constitucionales y en relación con el poder legislativo. ${ }^{29}$ Por otro lado, la Constitución de 1999 aumentó las facultades del Presidente al otorgarle competencias nuevas o que antes estaban reservadas al Congreso ya sea por ley, o mediante autorizaciones o aprobaciones, como son los casos, entre otros, de la creación (modificación o eliminación) de Ministerios determinando sus competencias; ${ }^{30}$ el ascenso de oficiales militares a partir del cargo de coronel o capitán de navío; ${ }^{31}$ las materias en las cuales puede ser habilitado para dictar decretos leyes; 32 y la disolución de la A samblea Nacional en caso de que sea removido el Vicepresidente Ejecutivo en tres oportunidades por voto de censura de la Asamblea Nacional en un mismo período constitucional (debiendo convocarse de inmediato a elecciones legislativas). ${ }^{33}$

En consecuencia, el Presidente de la República en la Constitución de 1999 ganó poderes respecto a lo establecido en la Constitución de 1961: no sólo porque su período pasó de 5 a 6 años, pudiendo además ser reelecto de inmediato; sino además, por las facultades adicionales que vimos arriba. Pero además, en la práctica, el Presidente ha sido más poderoso que muchos otros en nuestra historia, no sólo por los inmensos ingresos públicos que ha tenido el país en estos años provenientes del petróleo, sino por elementos esenciales como la falta de independencia de los demás poderes públicos, los cuales han pasado a depender políticamente del Ejecutivo Nacional. Esta falta de

28 Art. 230, Constitución de 1999.

29 Arts. 238 a 241, Constitución de 1999.

30 Art. 236, numeral 20, Constitución de 1999.

31 Art. 236, numeral 6, Constitución de 1999.

32 Art. 236, numeral 8 y art. 203, último aparte, Constitución de 1999.

33 Art. 236, numeral 21 y art. 240, Constitución de 1999. 
independencia ha llevado en la práctica a una inexistencia de los controles constitucionales que deben ejercer sobre el Presidente órganos como la Asamblea Nacional, el Tribunal Supremo de Justicia, la Defensoría de Pueblo, la Contraloría General y la Fiscalía General de la República. Además de ello es evidente la discrecionalidad con la cual se han administrado los recursos públicos a través de mecanismos que no por creativos, efectivos o innovadores, carecen de verdaderos controles.

Hugo Chávez fue electo en diciembre de 1998 bajo la Constitución de 1961, por un período de cinco años, ello es, del 2 de febrero de 1999 hasta el 2 de febrero de 2004. No obstante, al aprobarse la nueva Constitución de 1999, se convocó a elecciones generales el 28 de julio del año 2000. En dichas elecciones resultó ganador Hugo Chávez, con dos características constitucionales resaltantes. En primer lugar, que esa elección luego de casi dos años de ejercicio de la presidencia, no sólo no presentó ningún problema para la elección y la candidatura de un Presidente en ejercicio y candidato simultáneamente, sino que esta segunda elección tampoco fue calificada como reelección, sino como una nueva y primera elección. En segundo lugar, el Presidente Hugo Chávez electo originalmente en diciembre de 1998 bajo la Constitución de 1961, una vez aprobada la Constitución de 1999 fue (re)electo bajo esta nueva Carta el 28 de julio del año 2000 y tomó posesión del cargo de Presidente de la República el día 19 de agosto de ese mismo año 2000. Por lo cual, si la Constitución establece que el período del mandato del Presidente es de seis años, y éste tomó posesión del cargo el 19 de agosto de 2000, entonces su mandato debía terminar el 19 de agosto de 2006. Sin embargo, esta simple operación lógica de matemáticas fue desafiada en virtud del llamado régimen transitorio interpretado por la Sala Constitucional del Tribunal Supremo de Justicia (SC/TSJ). El problema se planteó por el hecho de que la Constitución también establece que el Presidente de la República tomará posesión del cargo el "diez de enero del primer año de su período constitucional".34 En consecuencia, supuestamente se presentaba un pretendido "vacío" interpretativo sobre la situación planteada en virtud de que el período de seis (6) años del Presidente Chávez terminaría el 19 de agosto del año 2006 y el próximo Presidente tomaría posesión el 10 de enero del año 2007. En el recurso de interpretación constitucional se preguntaba además cómo se llenaría ese vacío entre esas dos fechas. El asunto fue resuelto por la SC/TSJ mediante la sentencia de un recurso de interpretación constitucional de los artículos 230 y 231 de la Constitución, 16 del Régimen de Transición del Poder Público, y 3 y 31 del Estatuto Electoral del Poder Público (estos dos últimos dictados por la Asamblea Nacional Constituyente). Tras una cuestionable interpretación que la sentencia denominó una "opción ideológica por un determinado sentido político de la Constitución vigente" y expresando que la reducción o extensión del mandato "no parece afectar ni la intervención ciudadana, ni la intensidad del control popular, ni las posibilidades de su alternabilidad", la Sala Constitucional mediante sentencia de fecha 5 de abril del año $2001^{35}$ confirmada por la sentencia de fecha 16

Artículo 231, Constitución de 1999.

35 Caso: Francisco Encinas Verde y otros, ver referencia de sentencias del Tribunal Supremo de Justicia de Venezuela en: www.tsj.gov.ve 
de mayo de $2001{ }^{36}$ concluyó determinando que el período constitucional del Presidente Chávez concluiría el 10 de enero del año 2007. Entonces, por disposición de esta interpretación de la Sala Constitucional, el mandato del Presidente Chávez iniciado el 19 de agosto del año 2000 quedó extendido hasta el 10 de enero del año 2007, ello es, con una duración de 6 años, 4 meses y 22 días (en lugar de 6 años).

En el año 2004, luego de una serie de obstáculos e inconvenientes, la oposición y la sociedad civil lograron recoger las firmas requeridas para convocar a un referendo revocatorio, el cual se llevó a cabo el 15 de agosto de 2004, sin haber podido lograr la revocatoria del mandato del Presidente Chávez. ${ }^{37}$

Finalmente, en las elecciones presidenciales celebradas en diciembre de 2006 para el período 2007-2012, resultó reelecto el Presidente-candidato Hugo Chávez Frías.

\section{B. El Poder Legislativo}

a. La Constitución de 1961 y la Enmienda № 2. Durante el período 1975-2005 continuó desarrollándose el Poder Legislativo, regulado en la Constitución de 1961 con los cambios introducidos en 1983 por la Enmienda № 2; y luego, como se verá más adelante, a partir de 1999 por la nueva Constitución.

El Poder Legislativo Nacional bajo la Constitución de 1961, tenía como órgano al Congreso de la República, integrado por dos Cámaras: la de Diputados y el Senado..$^{38}$ La función de legislar le correspondió así a este Congreso bicameral, ${ }^{39}$ siendo indiferente la cámara de inicio de los proyectos de ley, excepto los relativos a las leyes de aprobación de los tratados y convenios internacionales que correspondían al Senado, ${ }^{40}$ y a la Cámara de Diputados los correspondientes a las leyes de presupuesto y régimen tributario. ${ }^{41}$

El período constitucional de los senadores y diputados del Congreso al igual que el período constitucional del Presidente de la República duraba cinco (5) años. ${ }^{42}$ Las funciones de control de la administración pública correspondían a ambas cámaras, siendo la del Senado especializada en los asuntos internacionales, militares y presidenciales; ${ }^{43}$ y la de Diputados en la responsabilidad política de los ministros mediante el "voto de censura". ${ }^{44}$

36 Caso: William Lara. El razonamiento de la SC/TS) en su sentencia de fecha 5 de abril del año 2001 (caso: Francisco Encinas Verde y otros) fue ratificada en la sentencia de fecha 16 de mayo de 2001 (caso: William Lara).

37 Para un estudio de los detalles de la convocatoria y celebración de este referendo revocatorio del Presidente de la República, puede consultarse el libro: A yalA Corao, Carlos, El referendo revocatorio. Ediciones El Nacional. Caracas. 2004.

38 Art. 138, Constitución de 1961.

39 Art. 139, Constitución de 1961.

40 Art. 150, ordinal 1ำ, Constitución de 1961.

41 Art. 153, ordinal 1으, Constitución de 1961.

42 Art. 135, Constitución de 1961.

43 Art. 190, ordinales 2ํal 8ำ, Constitución de 1961.

44 Art. 153, ordinal 2ํㅡ, Constitución de 1961. 
La función legislativa del Congreso fue objeto de modificación constitucional en el año 1983 mediante la Enmienda № 2 a la Constitución de 1961.45 Mediante esta enmienda se creó la Comisión Legislativa del Congreso, la cual por autorización de éste podría aprobar proyectos de ley por la mayoría de dos terceras partes de sus miembros. ${ }^{46}$ Posteriormente, las Cámaras del Congreso reunidas en sesión conjunta especialmente convocada para ello, podían rechazar o aprobar simplemente o con modificaciones dicho proyecto de ley, el cual en estos últimos casos quedaba sancionado como ley, debiendo cumplir subsiguientemente los demás trámites constitucionales para su promulgación y publicación. ${ }^{47}$

La otra modificación introducida al Congreso por la Enmienda № 2 de la Constitución de 1961, fue con relación al quórum para funcionar y sesionar: la Constitución de 1961 establecía que el quórum para el funcionamiento de la Cámaras no podía ser en ningún caso, "inferior a la mayoría absoluta de los miembros de cada Cámara". ${ }^{48}$ En su lugar, la Enmienda № 2 autorizó a las Cámaras a sesionar y funcionar, con el número de sus miembros que determine el reglamento, "el cual en ningún caso podrá ser inferior a la tercera parte de sus integrantes". Sin embargo, para el acto de votación debían estar presentes "la mayoría absoluta de los miembros de las Cámaras" ${ }^{49}$

b. La Constituyente de 1999. Una vez electa e iniciado el funcionamiento de la Asamblea Nacional Constituyente (ANC), tempranamente, el 12 de agosto de 1999, ésta dictó el Decreto de Reorganización de todos los órganos del Poder Público, ${ }^{50}$ mediante el cual declaró la "reorganización de todos los órganos del Poder Público", a cuyo fin dispuso que decretaría "las medidas necesarias para enfrentar situaciones específicas de la reorganización y dispondrá la intervención, modificación o suspensión de los órganos del Poder Público que así considere". ${ }^{51}$

Este primer Decreto anunciaba por tanto la intervención de la normalidad constitucional de los poderes públicos regulada en la Constitución de 1961, aun antes de aprobarse una nueva constitución.

La ANC dictó un primer Decreto de Regulación de las Funciones del Poder Legislativo el 25 de agosto de $1999,{ }^{52}$ el cual tuvo que ser modificado y dictado nuevamente el 30 de agosto de $1999 .{ }^{53} \mathrm{El}$ objeto de ese Decreto fue intervenir y modificar la

45 La Enmienda № 2 de la Constitución de 1961 fue sancionada por el Congreso el 16 de marzo de 1983 y publicada en la Gaceta Oficial № 3.224 Extraordinario de 24-7-83.

46 La Comisión Legislativa estaba compuesta por veintitrés (23) miembros del Congreso de la República, entre sus diputados y senadores, quienes eran designados en cada período constitucional por las Cámaras en sesión conjunta, de modo que reflejen en lo posible la composición política del Congreso (art. 4, Enmienda № 2 de la Constitución de 1961).

47 Artículo 5, Enmienda № 2 de la Constitución de 1961.

48 Art. 156, Constitución de 1961.

49 Artículo 6, Enmienda № 2 de la Constitución de 1961.

50 Publicado en Gaceta O ficial № 36.764 de fecha 13 de agosto de 1999.

51 Artículo Único, Decreto de Reorganización de todos los órganos del Poder Público.

52 Publicado en Gaceta O ficial № 36.772 de fecha 25 de agosto de 1999.

53 Publicado en Gaceta Oficial № 36.776 del 31 de agosto de 1999. Los artículos contenidos en el Decre- 
vigente Constitución de 1961 en lo relativo a las funciones de los órganos legislativos tanto a nivel nacional (Congreso), estadal (A sambleas Legislativas) y Municipal (Concejos M unicipales). De esta forma, aun sin derogarse la Constitución de 1961, la ANC se manifestó como poder originario con plenos poderes para modificar la Constitución y regular el régimen de los poderes constituidos. Se trató por tanto de otra fuerte oleada para desmontar por esta vía el ordenamiento constitucional, aun antes de aprobarse una nueva Constitución. Con ello, como se verá, quedaba destruida la idea misma del Estado Constitucional, ya que la Constitución "transitoria" había pasado a ser lo que la ANC decidiera libremente fuese y sin ningún control sobre ello.

En relación al Poder Legislativo Nacional, el Decreto dispuso la intervención de las competencias constitucionales del Congreso de la República, fijando los términos de las mismas, entre las cuales resaltamos las siguientes: ${ }^{54}$

1. La legislación sobre el régimen financiero y presupuestario, sujeta a ratificación de la A samblea Nacional Constituyente;

2. La legislación referida al régimen tributario, sujeta a ratificación de la A samblea Nacional Constituyente, así como las autorizaciones que dicha legislación establezca;

3. La autorización por ley especial al Ejecutivo Nacional para dictar medidas extraordinarias en materia económica y financiera, sujeta a ratificación de la A samblea Nacional Constituyente;

4. La legislación aprobatoria de los tratados y convenios internacionales a iniciativa del Ejecutivo Nacional, sujeta a ratificación de la A samblea Nacional Constituyente;

5. La legislación sobre telecomunicaciones, sujeta a ratificación de la Asamblea Nacional Constituyente;

6. La legislación referida al problema informático del año 2000, sujeta a ratificación de la Asamblea Nacional Constituyente;

7. La realización de las investigaciones que juzgue convenientes para dar cumplimiento a las funciones expresamente señaladas en el Decreto.

Asimismo, en relación con al funcionamiento del Congreso tanto en sus Cámaras tanto de Diputados como del Senado, el Decreto dispuso que quedaban "suspendidas las sesiones ordinarias y extraordinarias del Congreso de la República, así como cualquier otra actividad de las Cámaras"; y sus funciones se ejercerían por órgano de la Comisión Delegada, así como a través de las Comisiones de Finanzas, la Comisión de Contraloría y las Comisiones Especiales para el estudio del Informe A nual del Contralor General de la República y para la Reestructuración Administrativa del Congreso, ya que, igualmente quedaban suspendidas las sesiones de las otras Comisiones de dicho Congreso. La ANC quedaba incluso facultada para asumir las funciones de estas Comi-

to anterior que resultaron modificados o suprimidos por este Decreto fueron los siguientes: el artículo 2 sobre los órganos para el ejercicio de las funciones del Congreso, fue modificado; el artículo 11 sobre el órgano para el ejercicio de las funciones de las A sambleas Legislativas de los Estados, fue modificado; el artículo 12 sobre la revocatoria de la inmunidad, prerrogativas, privilegios y remuneraciones de los Diputados Estadales, fue suprimido; y el artículo 14 sobre la prohibición de los Concejos M unicipales fue modificado.

54 Artículo 1, Decreto de Regulación de las Funciones del Poder Legislativo. 
siones parlamentarias del Congreso que quedaban, en caso de que de alguna manera, se presumiera el no cumplimiento de esas funciones. ${ }^{55}$

En relación al Poder Legislativo de los Estados, el Decreto dispuso así mismo la intervención de las competencias constitucionales de las Asambleas Legislativas, fijando su forma de integrarse y los términos de las mismas, entre las cuales resaltamos las siguientes: ${ }^{56}$

Se suspendieron las sesiones de las A sambleas Legislativas en pleno, y en su lugar, sus funciones se ejercerían por órgano de una Comisión Delegada no mayor de siete (7) miembros e integrada solamente por Diputados principales, en representación proporcional de las fracciones políticas presentes en la A samblea Legislativa, garantizando en todo caso, la participación de por lo menos un representante de cada fracción.

Como consecuencia, el Decreto dispuso que los diputados de las Asambleas Legislativas de los Estados que no integrasen la Comisión Delegada, cesaban en sus funciones y, por lo tanto, no gozarían de inmunidad, ni de prerrogativa parlamentaria alguna, ni podían cobrar dieta o remuneración de ninguna especie, que se derive del ejercicio de sus funciones parlamentarias.

Por último, las A sambleas Legislativas que no diesen cumplimiento a esta disposición cesaban totalmente en sus funciones y una Comisión designada por la A samblea Nacional Constituyente, en un número no mayor de siete (7) miembros, asumiría las funciones de la Comisión Delegada respectiva.

Finalmente, en relación a los M unicipios, el Decreto dispuso una intervención moderada de las competencias constitucionales de los Concejos Municipales como órganos del poder legislativo local (y de la administración municipal), al establecer que los Municipios no podían enajenar, ni afectar de forma alguna, los ejidos ni bienes municipales; y tampoco podían aprobar o modificar el Plan de Desarrollo Urbano Local durante la vigencia del Decreto. ${ }^{57}$

Habiendo sido demandada la constitucionalidad de este Decreto, la Corte Suprema de Justicia en Pleno, en una votación muy controvertida que causó posteriormente la renuncia de varios de sus jueces, decidió mediante sentencia de fecha 6 de octubre de 1999, mantener la validez del mismo, con el argumento del "carácter presupuesto y supraconstitucional" de las normas aprobadas por la ANC en representación del poder constituyente originario.

Finalmente, dos días antes de la publicación de la nueva Constitución aprobada por la $\mathrm{ANC}^{58}$ ésta dictó un nuevo decreto mediante el cual, como se dijo, aun antes de

\footnotetext{
Artículo 2, Decreto de Regulación de las Funciones del Poder Legislativo.

Artículo 11, Decreto de Regulación de las Funciones del Poder Legislativo.

Artículo 13, Decreto de Regulación de las Funciones del Poder Legislativo.

58 La Constitución de la República Bolivariana de Venezuela, aprobada mediante referendo el 15 de agosto de 1999, fue publicada el 30 de diciembre de 1999 en la Gaceta Oficial № 36.860 .
} 
entrar en vigencia la Constitución, reorganizó las autoridades de los poderes públicos y nombró nuevas autoridades, sin seguir las formalidades exigidas por la nueva Carta. Ello se llevó a cabo, a través del Decreto sobre el Régimen de Transición del Poder Público.

En relación al Poder Legislativo Nacional el Decreto declaró “la disolución del Congreso de la República y, en consecuencia, la cesación en sus funciones de los senadores y diputados electos que lo integraban". ${ }^{59}$

De una manera insólita, la ANC auto engendró y dio a luz al órgano sustituto de Poder Legislativo Nacional sin elección alguna, al disponer hasta tanto se elijan y tomen posesión los diputados integrantes de la A samblea Nacional prevista en la nueva Constitución, aquél sería ejercido por una "Comisión Legislativa Nacional", la cual estaría integrada por veinte (20) ciudadanos, diez (10) Constituyentes que se "mutaron" en legisladores ordinarios y lo que fue peor, diez (10) ciudadanos de la calle que fueron insólitamente investidos por la ANC como legisladores. ${ }^{60}$ Esta Comisión Legislativa Nacional quedó facultada mediante el Decreto con las facultades propias de un Congreso o Asamblea Nacional, como son: ${ }^{61}$

A esta institución antidemocrática se le llamó popularmente el "Congresillo", ejerció funciones desde (la cesación de la ANC) el 1ำ de febrero del año 2000 hasta el mes de septiembre de ese año 2000 cuando se instaló la nueva Asamblea Nacional electa. ${ }^{62}$ Pero este Congresillo efectivamente llegó a legislar incluso a crear delitos en el Código Penal ${ }^{63}$ y en otras leyes como la Ley Sobre el Hurto y Robo de Vehículos A utomotores ${ }^{64}$ y modificó el Código Orgánico Procesal Penal; ${ }^{65}$ creó impuestos, ${ }^{66}$ y dictó otras "leyes" como la Ley Orgánica de Telecomunicaciones, ${ }^{67}$ entre otras. ${ }^{68}$ Se trató de una abierta violación al principio democrático de la representación popular por elección del pueblo y de la prohibición de legislar sin ser electo.

9 Artículo 4, Decreto sobre el Régimen de Transición del Poder Público.

60 Artículo 5, Decreto sobre el Régimen de Transición del Poder Público.

1 Artículo 6, Decreto sobre el Régimen de Transición del Poder Público.

2 Artículo 7, Decreto sobre el Régimen de Transición del Poder Público.

63 Gaceta Oficial № 5.494 Extraordinario de fecha 20 de octubre de 2000.

64 Gaceta Oficial. N³7.000 de 26 de julio de 2000.

65 Gaceta Oficial № 37.022 de 25 de agosto de 2000.

66 A través de la Ley que Establece el Impuesto al Valor Agregado (G.O. № 37.002 de 28-7-2000).

67 Gaceta Oficial № 36.970 de 16 de junio 2000.

68 El llamado "Congresillo" también dictó la Ley de Amnistía Política General (G.O. № 36.934 de 17-42000), la Ley de Corporación para la Recuperación y Desarrollo del Estado Vargas (G.O. № 36.968 de 8-6-2000), la Ley del Régimen Penitenciario (G.0. № 36.975 de 19-6-2000), la Ley de Conservación y Saneamiento de Playas (G.O. № 36.976 de 20-6-2000), la Ley de Reactivacion de la Marina Mercante Nacional (G.O. N 36.980 de 26-6-2000), la Ley de Geografía, Cartografía y Catastro Nacional (G.O. № 37002 de 28-7-2000), la Ley de Transición del Distrito Federal al Distrito Metropolitano de la Ciudad de Caracas (G.O. № 37.006 de fecha 3-8-2000), la Ley de Medicamentos (G.0. № 37.006 de 3-82000), la Ley del Instituto Nacional de Investigaciones A grícolas (G.O. № 37.022 de 25-8-2000), la Ley de Asignaciones Económicas Especiales para los Estados Derivadas de Minas e Hidrocarburos (G.O. № 37.022 de 25-8-2000) y la Ley Orgánica de la Administración Financiera del Sector Público (G.O. № 37.029 de 5-9-2000). 
En cuanto al Poder Legislativo de los Estados, el Decreto declaró la "disolución de las Asambleas Legislativas de los Estados" y la cesación "en sus funciones de los diputados que las integran". ${ }^{69}$ Hasta tanto se elegían y tomaran posesión los diputados integrantes de los Consejos Legislativos de los Estados previstos en la Constitución de 1999, el Decreto dispuso que el Poder Legislativo de cada Estado sería ejercido por una "Comisión Legislativa Estadal" integrada por cinco ciudadanos escogidos por la Comisión Coordinadora de la A samblea Nacional Constituyente. ${ }^{70}$ Estas Comisiones Legislativas de los Estados ejercerían las competencias otorgadas por la Constitución a los Consejos Legislativos. ${ }^{71}$

Y en relación con los órganos del Poder Público Municipal, el Decreto dispuso que los Concejos Municipales, así como los Alcaldes actuales, ejercieran sus funciones bajo la supervisión y control de la A samblea Nacional Constituyente o de la Comisión Legislativa Nacional, hasta tanto se eligieren popularmente sus nuevos integrantes. No obstante ello, La Comisión Coordinadora de la A samblea Nacional Constituyente o la Comisión Legislativa Nacional quedaron facultadas para sustituir parcial o totalmente la integración de los Concejos Municipales, así como sustituir a los Alcaldes, en los casos de "graves irregularidades administrativas". ${ }^{72}$

El decreto también procedió a designar provisionalmente mientras la Asamblea Nacional designara al titular de conformidad con la Constitución aprobada, a las siguientes autoridades: Defensor del Pueblo, ${ }^{73}$ Fiscal General de la República; ${ }^{74}$ y Contralor General de la República. ${ }^{75}$ El Contralor General de la República así designado, quedó facultado por el Decreto para intervenir las Contralorías de los Estados y Municipios, así como designar con carácter provisional a los Contralores de los Estados y Municipios que lo ameritaban. ${ }^{76}$

Finalmente, la ANC se reservó la designación de los integrantes del Consejo Nacional Electoral con carácter provisorio hasta que la A samblea Nacional haga las designaciones definitivas de conformidad con la Constitución aprobada. ${ }^{77}$

De esta forma, la Constitución de 1961 fue paulatinamente desmontada desde la instalación de la ANC y la aprobación de su Estatuto; y luego con los distintos decretos dictados por la ANC que la fueron derogando paulatinamente sin ningún control constitucional, lo cual fue avalado por la Corte Suprema de Justicia aun antes de su desaparición en la sentencia citada supra.

\footnotetext{
Artículo 11, Decreto sobre el Régimen de Transición del Poder Público. Artículo 12, Decreto sobre el Régimen de Transición del Poder Público. Artículo 13, Decreto sobre el Régimen de Transición del Poder Público. Artículo 15, Decreto sobre el Régimen de Transición del Poder Público. Artículo 35, Decreto sobre el Régimen de Transición del Poder Público. Artículo 36, Decreto sobre el Régimen de Transición del Poder Público. Artículo 37, Decreto sobre el Régimen de Transición del Poder Público. Artículo 38, Decreto sobre el Régimen de Transición del Poder Público.

Artículo 41, Decreto sobre el Régimen de Transición del Poder Público.
} 
La nueva Constitución había así nacido violada, pero luego del copamiento de los poderes públicos su vigencia quedó aun más comprometida. Es este nuevo esquema, si bien en teoría el control judicial de la Constitución fue ampliado, la composición de la Sala Constitucional del nuevo Tribunal Supremo de Justicia aseguró el control del poder político sobre la interpretación constitucional. ${ }^{78}$

c. La Constitución de 1999: Unicameralismo en un sistema federal. La Constitución de 1999 estableció un poder legislativo unicameral en un "Estado federal descentralizado", ${ }^{79}$ dividido político territorialmente en un Poder Público Estadal integrado por estados como entidades autónomas, ${ }^{80}$ y en un Poder Público M unicipal integrado por municipios como la unidad política primaria, ${ }^{81}$ amén de un Distrito Capital| ${ }^{82}$ y un Distrito Metropolitano de Caracas, ${ }^{83}$ todos con personalidad jurídica.

A pesar del carácter federal y del Bicameralismo venezolano desde los inicios de la república en la Constitución de 1811 y hasta la de 1961, con un discurso demagógico sobre la abolición de Senado por ser supuestamente "innecesario" y "costoso", la ANC tomó la decisión de eliminar dicha Cámara en la Constitución de 1999 y optar por un Poder Legislativo Nacional unicameral: la Asamblea Nacional. Ésta está integrada por Diputados electos de la siguiente manera: ${ }^{84}$

1. Los diputados elegidos en cada entidad federal (los estados y el Distrito Capital) por votación universal, directa, personalizada y secreta con representación proporcional, según una base poblacional del uno coma uno por ciento de la población total del país.

2. Luego de eliminado el Senado se pretendió corregir parcialmente el error introduciendo un elemento de igualdad federal al establecer que cada entidad federal elegirá, además, tres diputados o diputadas.

3. Tres diputados electos por los pueblos indígenas, de acuerdo con lo establecido en la ley electoral, respetando sus tradiciones y costumbres. ${ }^{85}$

78 Ver, entre otros, de autores varios (Chavero, Rafael; Brewer-Carías, Allan; Duque, Román), La Guerra de las Salas, Caracas, 2004. Ayala Corao, Carlos. El Refrendo Revocatorio. Caracas, 2004.

79 Art. 4, Constitución de 1999.

80 Art. 159, Constitución de 1999.

81 Art. 168, Constitución de 1999.

82 Art. 16, Constitución de 1999.

83 Art. 18, Constitución de 1999.

84 Art. 186, Constitución de 1999.

85 M ientras la ley electoral regulara la materia, la Disposición Transitoria Séptima de la Constitución de 1999 estableció la siguiente forma de elección de los diputados nacionales, estadales y concejales indígenas:

Disposición Transitoria Séptima. A los fines previstos en el artículo 125 de esta Constitución, mientras no se apruebe la ley orgánica correspondiente, la elección de los y las representantes indígenas a la A samblea Nacional, a los Consejos Legislativos y a los Concejos M unicipales, se regirá por los siguientes requisitos de postulación y mecanismos:

Todas las comunidades u organizaciones indígenas podrán postular candidatos y candidatas que sean indígenas.

Es requisito indispensable, para ser candidato o candidata, hablar su idioma indígena y cumplir con, al menos, una de las siguientes condiciones:

1. Haber ejercido un cargo de autoridad tradicional en su respectiva comunidad. 
Con la Constitución de 1999 los períodos de los diputados a la A samblea Nacional y el del Presidente de la República ya no coinciden como en la Constitución de 1961, ya que el de la primera es de cinco (5) años, ${ }^{86}$ y como vimos supra, el del segundo es de seis (6) años. No obstante, dicho mandato, como el de todos los cargos de elección popular, puede ser revocado. ${ }^{87} \mathrm{Y}$ en caso de que el mandato de un diputado sea revocado, no podrá optar a cargos de elección popular en el siguiente período. ${ }^{88}$

Por otro lado, la Constitución de 1999 introdujo una limitación a la reelección de los diputados: sólo pueden ser reelectos por dos períodos consecutivos como máximo. ${ }^{89}$

El resto de las regulaciones de la Constitución de 1999 sobre el Poder Legislativo Nacional y sus integrantes, son en términos generales similares a las contenidas en la Constitución de 1961, en materias como los privilegios de irresponsabilidad por los votos y opiniones emitidos por los diputados en el ejercicio de sus funciones ${ }^{90}$ y la inmunidad parlamentaria; ${ }^{91}$ la iniciativa de ley; ${ }^{92}$ procedimiento para la aprobación de leyes y veto presidencial. ${ }^{93}$ Sin embargo, la Constitución de 1999 incorporó normas relativas a la participación ciudadana y de la sociedad civil en el procedimiento de discusión legislativa. ${ }^{94}$ Así mismo, para el caso de las iniciativas ciudadanas de proyectos leyes (que corresponde a un número no menor del cero coma uno por ciento de los electores inscritos en el Registro Electoral ${ }^{95}$ ) no discutidas oportunamente por la Asamblea Nacional, la Constitución dispuso una suerte de "legislación directa", ya

2. Tener conocida trayectoria en la lucha social en pro del reconocimiento de su identidad cultural.

3. Haber realizado acciones en beneficio de los pueblos y comunidades indígenas.

4. Pertenecer a una organización indígena legalmente constituida con un mínimo de tres años de funcionamiento.

Se establecerán tres regiones: Occidente, compuesta por los Estados Zulia, M érida y Trujillo; Sur, compuesta por los Estados A mazonas y A pure; y Oriente, compuesta por los Estados Bolívar, Delta Amacuro, Monagas, Anzoátegui y Sucre.

Cada uno de los Estados que componen las regiones elegirá un representante. El Consejo Nacional Electoral declarará electo al candidato o electa a la candidata que hubiere obtenido la mayoría de los votos válidos en su respectiva región o circunscripción.

Los candidatos o las candidatas indígenas estarán en el tarjetón de su respectivo Estado o circunscripción y todos los electores y electoras de ese Estado podrán votarlos o votarlas.

Para los efectos de la representación indígena en los Consejos Legislativos y en los Concejos M unicipales de los Estados y M unicipios con población indígena, se tomará el censo oficial de 1992 de la Oficina Central de Estadística e Informática. Las elecciones se realizarán de acuerdo con las normas y requisitos aquí establecidos.

El Consejo Nacional Electoral garantizará con apoyo de expertos o expertas indigenistas y organizaciones indígenas, el cumplimiento de los requisitos aquí señalados.

86 Art. 192, Constitución de 1999.

87 Art. 72, Constitución de 1999.

88 Art. 198, Constitución de 1999.

89 Art. 192, Constitución de 1999.

90 Art. 199, Constitución de 1999.

91 Art. 200, Constitución de 1999.

92 Art. 204, Constitución de 1999.

93 Arts. 205 al 218, Constitución de 1999.

94 Arts. 206 y 211, Constitución de 1999.

95 Art. 204, ordinal $7^{\circ}$, Constitución de 1999. 
que en caso de que su discusión no se inicie a más tardar en el período de sesiones ordinarias siguiente al que se haya presentado, el proyecto se someterá a referendo aprobatorio de conformidad con la ley. ${ }^{96}$

\section{Las relaciones entre el Ejecutivo y el Legislativo, bajo la Constitución de 1961 y bajo la Constitución de 1999}

El sistema de gobierno venezolano ha sido descrito como un "presidencialismo mixto" o un "presidencialismo con sujeción parlamentaria". En este sentido, bajo la Constitución de 1961 varias de las atribuciones del Presidente de la República estaban sometidas a control del Congreso de la República, y en concreto del Senado, como es el caso de los nombramientos de los jefes de misiones diplomáticas y del Procurador General de la República; ${ }^{97}$ el ascenso de oficiales de las Fuerzas A rmadas Nacionales, desde Coronel o Capitán de Navío, inclusive; ${ }^{98}$ la enajenación de bienes inmuebles del dominio privado de la Nación; ${ }^{99}$ el empleo de misiones militares venezolanas en el exterior o extranjeras en Venezuela; ${ }^{100}$ y la salida del Presidente de la República del territorio nacional, ${ }^{101}$ entre otras.

Esta relación de controles parlamentarios cedió a favor del Presidente de la República en la Constitución de 1999. A sí por ejemplo, en esta Constitución se eliminaron los controles parlamentarios de las facultades presidenciales relativas al ascenso de oficiales de las Fuerza Armada Nacional, desde Coronel o Capitán de Navío y la salida del Presidente de la República del territorio nacional.

Otra facultad del Presidente de la República que resultó aumentada peligrosamente y en contra de los tratados sobre derechos humanos, ${ }^{102}$ fue la relativa a la legislación por decretos leyes. Bajo la Constitución de 1961, el Congreso sólo podía habilitar al Presidente para dictar decretos leyes en "materia económica o financiera". ${ }^{103}$ Por lo cual, el Congreso, al sancionar las leyes habilitantes, determinaba las materias económicas o financieras y el tiempo por el cual autorizaba al Presidente a dictar decretos leyes. En cambio, bajo la Constitución de 1999, las facultades legislativas del Presidente de la República que la Asamblea Nacional puede habilitar mediante ley, no están circunscritas a las materias económicas o financieras, sino que se hace referencia abierta a "las materias". ${ }^{104}$ En nuestra opinión estas materias deben considerarse limitadas a las autorizadas por el derecho internacional de los derechos humanos. ${ }^{105}$

\footnotetext{
96 Art. 205, Constitución de 1999. El referendo aprobatorio de leyes está consagrado en el artículo 73.

97 Art. 190, ordinal 16으, Constitución de 1961.

98 Art. 150, ordinal 5ㅇ, Constitución de 1961.

99 Art. 150, ordinal 2º, Constitución de 1961.

100 Art. 150, ordinal 4ํㅡ, Constitución de 1961.

101 Art. 150, ordinal 6으, Constitución de 1961.

102 Nos referimos a las materias de reserva legal, tales como el establecimiento de delitos y penas, así como las restricciones únicamente mediante ley a los derechos humanos, conforme a los artículos 9 y 30 de la Convención Americana sobre Derechos Humanos.

103 Art. 190, ordinal 8o, Constitución de 1961.

104 Art. 203, último aparte, Constitución de 1999.

105 Ver en este sentido: Corte Interamericana de Derechos Humanos. La Expresión «Leyes» en el Artículo
} 
Otro de los elementos parlamentarios del sistema presidencial venezolano y por tanto de la relación entre el poder legislativo y el poder ejecutivo desde la Constitución de 1864, ha sido la atribución de la Cámara de Diputados de interpelar a los Ministros e imponerles un voto de censura que acarree su remoción. En este sentido, la Constitución de 1961 establecía entre las atribuciones de la Cámara de Diputados la de dar voto de censura a los Ministros, en cuyo caso, podía decidir por las dos terceras partes de los Diputados presentes, que dicho voto acarreara la remoción del M inistro. ${ }^{106}$

No obstante, por diversas razones relativas al funcionamiento del sistema político y luego del sistema de partidos y consensos, si bien la Cámara de Diputados emitió varios votos de censura, no llegaba a conseguir la mayoría calificada exigida para imponer la remoción del Ministro censurado. La remoción de un Ministro por un voto de censura de la Cámara de Diputados se logró imponer por primera vez en la historia de Venezuela en el año 1995, durante el segundo gobierno del Presidente Rafael Caldera. Se trataba de una situación en la cual el partido de gobierno (Convergencia) no contaba con más del $20 \%$ de la representación parlamentaria y lograba la mayoría con un acuerdo puntual con otros dos partidos (MAS y AD). No obstante, con ocasión de una crisis de salud grave ocurrida en el Estado Zulia, la Cámara de Diputados por primera vez en 1995 le impuso el voto de censura y removió por la mayoría calificada exigida al Ministro de Sanidad, Dr. Carlos Walter.

La Constitución de 1999, de manera similar a la Constitución de 1961 consagró la responsabilidad política de los M inistros ahora ante la A samblea Nacional, mediante el voto de censura; y su remoción la sujetó a una mayoría menos exigente, no menor de las tres quintas partes de los integrantes presentes de la A samblea Nacional. En este caso, la Constitución adecuadamente aclaró que el funcionario removido no podrá optar al cargo de M inistro, ni en su caso, de Vicepresidente Ejecutivo, por el resto del período presidencial. ${ }^{107}$

Por otro lado, la Constitución comenzó a desarrollar un sistema más complejo de incentivos y consecuencias para los impases entre el Legislativo y el Ejecutivo. Para ello, facultó a la Asamblea Nacional para dar el voto de censura al Vicepresidente Ejecutivo y decidir su destitución por las tres quintas partes de los diputados. ${ }^{108}$

No obstante, a fin de racionalizar este control, la Constitución dispuso que la remoción del Vicepresidente Ejecutivo en tres oportunidades dentro de un mismo período constitucional, como consecuencia de la aprobación de mociones de censura, faculta al Presidente o Presidenta de la República para disolver la Asamblea Nacional. En todo caso, el decreto presidencial de disolución conlleva la convocatoria de elecciones para una nueva legislatura dentro de los sesenta días siguientes a su disolución; y la Asamblea no podrá ser disuelta en el último año de su período constitucional. ${ }^{109}$

30 de la Convención A mericana sobre Derechos Humanos. Opinión Consultiva OC-6/86 del 9 de mayo de 1986. Serie A № 6.

106 Art. 153, ordinal 2o, Constitución de 1961.

107 Art. 246, Constitución de 1999.

108 Art. 187, numeral 10, Constitución de 1999.

109 Art. 240, Constitución de 1999. 


\section{EL PODER JUDICIAL}

\section{A. Consideraciones generales}

Una de las principales fragilidades de nuestra evolución institucional radica en el inadecuado funcionamiento e integración de la administración de justicia. La Constitución de 1961 proclamaba la autonomía de los jueces y preveía un poder judicial independiente, lo cual iba respaldado por el mandato de instaurar la carrera judicial y de asegurar la estabilidad de los jueces. A dicionalmente, se creaba el Consejo de la Judicatura, como instancia autónoma encargada del gobierno y administración del poder judicial, lo que comprendía la organización de la selección e ingreso de los jueces, así como su nombramiento y, eventualmente, su remoción por las causales legalmente fijadas. El Consejo de la Judicatura estaba llamado a asumir funciones que anteriormente ostentaba el Ejecutivo Nacional. Su funcionamiento no fue posible sino hasta 1969, cuando fue dictada la Ley Orgánica del Poder Judicial que reguló su conformación y atribuciones.

Desde entonces fue advertido el riesgo de politización de la justicia que implicaría su creación, dado el papel que se otorgaba al Congreso de la República y a los partidos políticos allí representados en la designación de sus miembros. Pero el origen del mal no estuvo tanto en este procedimiento sino en la actitud que adoptaron los órganos del Estado que debían tener presencia en ese cuerpo, que abrió las puertas al control partidista del Consejo de la Judicatura y, por esta vía, del entero poder judicial. En 1975 el proceso de dominio partidista de este órgano y de los tribunales se estaba desarrollando y, como veremos, no se detendría.

\section{B. Incumplimiento de los postulados constitucionales e iniciativas de reforma judicial}

La razón de ser del Consejo de la Judicatura fue tergiversada por la praxis institucional y el establecimiento de la carrera judicial fue un mandato constitucional incumplido. Habría que esperar a 1980 para la promulgación de la Ley de Carrera Judicial, que reguló las distintas etapas de esta carrera, desde la selección e ingreso de los jueces por concurso, pasando por su permanencia y ascenso, hasta llegar a la terminación de la carrera mediante jubilación, sin perjuicio de la posibilidad de destitución en virtud de la comisión de falta grave, previa instrucción del procedimiento correspondiente. Sin embargo, la carrera judicial no fue instaurada y el ingreso de los jueces no se sometía al procedimiento de los concursos.

En la segunda mitad de la década de los ochenta se plantea la necesidad de una reforma del Poder Judicial. La Comisión Presidencial para la Reforma del Estado (CO PRE), advertía que los postulados de la Constitución de 1961 no se habían satisfecho, a pesar de disponer de las previsiones normativas tendentes a afirmar la autonomía e independencia del Poder Judicial. En este sentido, se indicaba que: aún no se había creado plenamente la jurisdicción contencioso-administrativa (siendo regulada por las disposiciones transitorias de la Ley Orgánica de la Corte Suprema de Justicia); la Ley de 
Carrera Judicial era ineficaz en cuanto al mecanismo establecido para la selección de los jueces; los jueces no contaban con la cooperación de las entidades administrativas en lo que atañe a la ejecución de las sentencias, y que en muchos casos éstas eran desacatadas, siendo necesario "el reestablecimiento de la autoridad y majestad del juez"; 110 también había que hacer modificaciones a la organización del Máximo Tribunal, pues estaba sobrecargado de trabajo y sin recursos de apoyo a sus importantes funciones. Algunas de las propuestas fueron plasmadas en leyes, como ocurrió con la Ley Orgánica del Consejo de la Judicatura de 1988, que tuvo entre sus objetivos "el asignarle las atribuciones que debían corresponderle de acuerdo con su naturaleza de ente administrativo dedicado al gobierno judicial". ${ }^{111}$

Sin embargo lejos de producirse los cambios esperad os se mantuvieron agravadas las prácticas del pasado, en particular la designación de los jueces como parte de la política clientelar de los partidos. Si bien la integración del Consejo de la Judicatura (inicialmente, nueve miembros: cinco principales por la Corte Suprema, dos por el Congreso y dos por el Ejecutivo Nacional; y luego en 1988, cinco magistrados, tres designados por la Corte Suprema de Justicia, uno por el Congreso y otro por el Ejecutivo), pretendía establecer un punto de equilibrio entre los diversos poderes, degeneró en una representación de los principales partidos políticos: "en la práctica se sabe que son los partidos políticos quienes escogen a los magistrados y que éstos de una manera más o menos intensa, se sienten que representan los intereses de su partido". ${ }^{112}$ Esto explica que el régimen de concursos de oposición para el ingreso de los jueces previsto en la Ley de Carrera Judicial, tuvo muy poca eficacia, al presentar riesgos para el control partidista. ${ }^{113}$

Hubo otras iniciativas de cambios en esa época, propiciadas por el mismo Consejo de la Judicatura para mejorar la eficiencia de los tribunales sobre todo en materia penal, pues resultaba alarmante que en las cárceles el porcentaje de presos sin sen-

110 COPRE: Reformas inmediatas al Poder Judicial. Cuadernos para la Discusión № 5. Ediciones COPRE, Caracas, Venezuela. 1987, cit., en COPRE: Fortalecimiento del Estado de Derecho. Vol. 5. Caracas, 1990 , p. 47.

111 Se trataba de la Ley Orgánica del Consejo de la Judicatura de 1988 (G.O. № 34.068 del 7 de octubre de 1998).

112 Pérez Perdomo, Rogelio: Políticas Judiciales en Venezuela. Ediciones IESA. Estudios IESA № 31995. Caracas, p. 33.

$113 \mathrm{lb} ., \mathrm{p}$. 33. Puede especularse incluso que las veces en que se ha procedido a la apertura de los concursos, corresponde más bien a la coyuntura vigente y no a una política sistemática. "Al comienzo de la década de 1970, el Consejo de la Judicatura organizó concursos de oposición para la designación de jueces. Poco tiempo después, el Consejo de la Judicatura suspendió los concursos de oposición y se consolidó la práctica de designar jueces suplentes o provisorios, y sólo esporádicamente se realizaron concursos". Dirección Ejecutiva de la Magistratura, Unidad Coordinadora del Proyecto de Modernización del Poder Judicial: Proyecto para la Mejora de la Administración de Justicia en el Contexto de la Resolución de Conflictos en Venezuela. S/p. Caracas, mayo 2003. Hacia 1998, el Consejo de la Judicatura hizo intentos por implementar el proceso de concursos de oposición, que no logró tener resultados en dicho sentido. Después de la entrada en vigencia de la Constitución, también la Comisión Coordinadora de Evaluación y Concursos para el Ingreso y Permanencia en el Poder Judicial inició con mucho impulso el proceso de concursos, pero fueron suspendidos desde mediados de este año, sin que se cumplieran los objetivos previstos. 
tencia (60\%) era superior a los condenados, problema derivado de la acumulación de las causas y la lentitud de los juicios. De este modo se implementaron medidas como la de los jueces itinerantes (1989), electos inicialmente por concurso y dependientes del Consejo de la Judicatura, siendo aparentemente efectivos por la cantidad de sentencias dictadas, pero paradójicamente sin que ello produjera menor cantidad de presos no condenados en las cárceles, por el aumento de la delincuencia y la lentitud de la justicia penal. Otro programa de reformas fue el de la informatización de los tribunales, basado únicamente en la introducción de tecnología, sin cambios en la estructura del tribunal, que tampoco tuvo resultados visibles en el aumento de la eficiencia.

En los años 90 continuaron los intentos de transformación de la justicia, pudiéndose hablar de una segunda oleada de reformas esta vez con el apoyo de las agencias internacionales de financiamiento y cooperación económica como el Banco Mundial y el Banco Interamericano de Desarrollo. En parte, la preocupación por el tema del funcionamiento del Poder Judicial y en general, el fortalecimiento del Estado de Derecho, se vinculó en un primer momento con la idea de dotar de seguridad jurídica a las inversiones, y así llevar a la práctica determinados proyectos políticos-económicos. ${ }^{114}$ Se entendía la seguridad jurídica en términos de seguridad de los contratos y de seguridad de la propiedad. Paralelamente, los intentos de reforma judicial y legislativa se encaminaron en este sentido. Con el Banco Mundial se celebró un proyecto de infraestructura de apoyo al Poder Judicial, en 1995; el objeto del convenio era la modernización del Consejo de la Judicatura, la construcción de sedes para los tribunales y la modernización de los tribunales de dos ciudades del país, que fueron Barcelona y Barquisimeto. Este convenio se ejecutó sin problemas hasta 1999, fecha en la que se paralizó por los acontecimientos políticos de dicho año. El otro convenio con el Banco M undial fue firmado en 1997, y estuvo dirigido al proceso de modernización de la entonces Corte Suprema de Justicia, cuyos resultados han sido calificados como exitosos. Ya en el 2001, se firmó un convenio con el Banco Interamericano de Desarrollo para la modernización y fortalecimiento del M inisterio Público y el M inisterio de Relaciones Interiores y de Justicia. Si se hace una sumatoria de los montos de dichos convenios puede decirse que en los últimos diez años ha habido una inversión importante en el sector justicia, incluyendo además otros tipos de ayuda como la realizada por el Programa de las Naciones Unidas para el Desarrollo (PNUD), que en el primer trimestre de 1998 integró una misión de expertos nacionales y extranjeros para realizar un profundo examen de la problemática de la justicia en Venezuela, identificando las fortalezas y debilidades del mismo, y concluyendo en un conjunto de proposiciones de reforma integral.

En este período, conviene hacer mención a la fuerte crisis de gobernabilidad sufrida entre 1989 y 1993, que puso de nuevo en el tapete el tema de la reforma del Estado, acelerando en dicho período la discusión de un Proyecto de Reforma General de la Constitución, donde fue de "excepcional importancia y de gran urgencia, la materia relativa a la administración de justicia". ${ }^{115}$ Sin embargo, dicha reforma no recibió la aprobación del Congreso.

114 Vid. Pérez Perdomo, Rogelio (coord.); Boza, María Eugenia y NJaim, Humberto: Seguridad Jurídica y Competitividad. IESA. Caracas. 1994.

115 Comisión Bicameral para la Revisión de la Constitución. Exposición de Motivos del Proyecto de Reforma General de la Constitución de 1961. Caracas, marzo de 1992. 
Si bien no se produjo la modificación de la Carta Magna, sí se introdujeron significativas innovaciones al sistema jurídico, como consecuencia de la sanción de una serie de leyes que afectaron positivamente al sector justicia. Así podemos mencionar la Ley Orgánica de la Justicia de Paz (1994), que adoptó esta jurisdicción no formal para resolver pequeños conflictos mediante la mediación, conciliación o adjudicación, erigiénd ose en un mecanismo para facilitar el acceso a la justicia de las clases pobres; el Código Orgánico Procesal Penal (1998), que pese a las críticas constituyó un significativo paso de avance, al cambiar un procedimiento prácticamente inquisitivo por un procedimiento acusatorio; la Ley Orgánica del Poder Judicial (1998), la Ley de Carrera Judicial (1998) y la Ley Orgánica del Consejo de la Judicatura (1999), que intentaron poner correctivos a los problemas esbozados, así como modernizar las estructuras judiciales, otorgándosele a la Corte Suprema de Justicia competencias en materia de políticas judiciales. La Ley Orgánica para la Protección del Niño y del Adolescente (1998) también transformó el modelo de justicia tutelar del menor.

No obstante, pareciera que no se tuvo la paciencia necesaria para evaluar el impacto de dichas modificaciones. Asíllegamos a agosto de 1999, fecha en la que se instala la A samblea Nacional Constituyente, electa por el pueblo con "el propósito de transformar el Estado y crear un nuevo ordenamiento jurídico que permitiera el funcionamiento efectivo de una Democracia Social y Participativa". Siendo el primer acto del nuevo órgano el "Estatuto de Funcionamiento de la A samblea Nacional Constituyente", ${ }^{116}$ mediante el cual se erige como poder originario depositario de la soberanía popular, quedando subordinados a su autoridad "todos los organismos (sic) del Poder Público", lo cual le sirvió de fundamento para "limitar o decidir la cesación de las actividades de las autoridades que conforman el Poder Publico, en uso de las atribuciones que le son inherentes". Ello sentó las bases para intervenir en la actuación de dos poderes: el Poder Judicial y el Poder Legislativo. Así mediante el Decreto de Reorganización del Poder Judicial (25-08-99), que declaró a dicho poder "en emergencia y reorganización" con el fin "de adecentar el sistema judicial", se procedió a la creación de una Comisión de Emergencia Judicial, de la cual formaría parte un Magistrado de la Corte Suprema de Justicia, cuyo objetivo principal era la elaboración del Plan Nacional de Evaluación y Selección de Jueces. ${ }^{117}$ Esta Comisión cumplió parcialmente la misión para la cual fue designada, al limitarse a realizar una serie de destituciones y suspen-

\footnotetext{
116 Publicado en la Gaceta Oficial 36.786, del 14 de septiembre de 1999.

117 Cabe destacar que con ocasión de dicho Decreto la Corte emitió un Acuerdo de fecha 23 de agosto de 1999, en el que reconoce que "El Decreto de Reorganización del Poder Judicial, con las particularidades que en definitiva el mismo establezca, y asimismo, independientemente de los vicios que pueden afectarlo, contempla un compromiso de la A samblea Nacional Constituyente de proceder de inmediato a través de una Comisión de Emergencia Judicial a la revisión de los expedientes de los jueces y su evaluación..."; igualmente el Máximo Tribunal de la República ofreció su "contribución para el objetivo fundamental perseguido por el Decreto", autorizando al Magistrado Alirio Abreu Burelli para que integrara la Comisión de Emergencia Judicial. A Igunos Magistrados salvaron su voto contra dicho Acuerdo, entre ellos, la Presidenta de la Corte para ese entonces, Dra. Cecilia Sosa, quien además renunció a su cargo de Presidenta del Máximo Tribunal, así como a su cargo de Magistrado, indicando que "al acatar el Decreto de la A samblea, la Corte Suprema de Justicia se autodisuelve". Voto salvado de la Magistrada Cecilia Sosa Gómez al texto del Acuerdo de la Corte Suprema de Justicia del 24-08-99.
} 
siones. Dicho proceso ha sido calificado por algunos como "una cacería de brujas contra funcionarios judiciales que produjo la destitución del 95\% de los jueces por supuestos casos de corrupción sin contar con el debido proceso". ${ }^{118}$

Con este negativo antecedente nace la Constitución de 1999, incorporando una serie de cambios en la organización del Poder Judicial y demás instituciones que intervienen en la administración de justicia.

\section{Cambios introducidos por la Constitución de 1999}

a. De la justicia como poder a la justicia como servicio. A unque la Constitución no lo señale expresamente puede decirse que hay un cambio en la concepción de la Justicia, ya no considerada exclusivamente como una de las ramas de la trilogía clásica del Poder Público, sino también como un servicio público cuya prestación debe garantizar el Estado, que genera obligaciones para los órganos de administración de justicia, y en caso de que no se imparta en la forma establecida, los ciudadanos podrían exigir la responsabilidad del Estado, de los jueces y funcionarios judiciales. Esto se pone de manifiesto en el artículo 26, que consagra el derecho de acceso a la justicia y a la tutela judicial efectiva, cuando se indica que: "El Estado garantizará una justicia gratuita, accesible, imparcial, idónea, transparente, autónoma, independiente, responsable, equitativa y expedita, sin dilaciones indebidas, sin formalismos o reposiciones inútiles". Ratifica esta idea el precepto contenido en la primera parte del artículo 253, al señalar que "la potestad de administrar justicia emana de los ciudadanos o ciudadanas y se imparte en nombre de la República y por autoridad de la ley".

Sin embargo, la realidad dista de la intención normativa, pues si bien se han hecho algunos esfuerzos orientados a provocar este giro, aún dicha idea no se ha interiorizado en la cultura de los jueces, produciéndose situaciones abusivas y hasta violatorias de los derechos de los ciudadanos por parte de algunos funcionarios judiciales.

b. Del sistema de justicia. Otra innovación del Texto Fundamental es la visión sistemática del sector justicia, integrado no sólo por el Poder Judicial (Tribunal Supremo de Justicia y demás tribunales de la República), sino también por el Ministerio Público, la Defensoría Pública, los órganos de investigación penal, los o las auxiliares y funcionarios o funcionarias de justicia, el sistema penitenciario, los medios alternativos de justicia, los ciudadanos que participan en la administración de justicia conforme a la ley y los abogados autorizados para el ejercicio". La ausencia del concepto de sistema era una de las fallas advertidas por el PNUD en 1998.

Tampoco el cambio normativo en este sentido ha tenido correspondencia con la práctica, evidenciándose la falta de coordinación y vinculación entre los distintos entes que forman parte y se relacionan con esta área. Así, por ejemplo, muchas veces la tardanza de los juicios no se debe a la actuación de los tribunales sino a las deficiencias

118 Informe elaborado por Consorcio Justicia sobre el sector Justicia en Venezuela. Caracas, 2003. 
en el desempeño de las funciones por parte de los otros entes que integran el sector justicia. Muestra de ello es que la inasistencia de los Fiscales del Ministerio Público a las audiencias produce importantes retardos en los juicios penales. En lo que concierne al sistema penitenciario, al no realizarse el traslado del procesado en las audiencias programadas o para la hora establecida, se genera un alargamiento del proceso.

c. Gobierno y administración del Poder Judicial. Las fallas advertidas en el funcionamiento del Consejo de la Judicatura, así como las continuas críticas de las cuales era objeto, llevaron a pensar en la idea de que la solución era aglutinar en un solo órgano, el Tribunal Supremo de Justicia, tanto la función de gobierno como las jurisdiccionales. De esta manera, el Máximo Tribunal no sólo es la instancia de mayor rango en el poder judicial sino también la encargada de la dirección, el gobierno y la administración del Poder Judicial, la inspección y vigilancia de los tribunales de la República y el sistema de la Defensa Pública.

Las funciones de gobierno le corresponden a la Sala Plena, mediante la Dirección Ejecutiva de la Magistratura (art. 267 CRBV). ${ }^{119}$ Para el control y supervisión del funcionamiento de la Dirección Ejecutiva de la Magistratura la Sala Plena creó la Comisión Judicial, integrada por seis mag istrados en representación de cada una de las Salas del Tribunal Supremo de Justicia y su Presidente.

d. Independencia del Poder Judicial. El texto constitucional declara expresamente la independencia del Poder Judicial, así como la autonomía funcional, financiera y administrativa del Tribunal Supremo de Justicia, para lo cual dispone que se destine no menos del $2 \%$ del presupuesto ordinario nacional al sistema judicial, monto que no puede ser reducido o modificado sin autorización previa de la Asamblea Nacional.

Otra regulación dirigida a propugnar la independencia del Poder Judicial es el sistema de selección de los M agistrados del Tribunal Supremo de Justicia, pues la Constitución prevé la creación de un Comité de Postulaciones Judiciales, como órgano asesor del Poder Judicial para la selección de los candidatos a dichos cargos, integrado por diferentes sectores de la sociedad, de conformidad con lo que establezca la ley. No obstante, el Constituyente no dispuso nada sobre la mayoría requerida para la selección de los Magistrados y estableció que su remoción puede ser acordada por la A samblea Nacional, por una mayoría calificada de las dos terceras partes de sus integrantes, lo cual ha sido criticado.

También en aras de garantizar la independencia de los jueces la Constitución consagra la carrera judicial, estableciéndose que el ingreso y ascenso de los jueces se hará por concursos públicos que aseguren la idoneidad y excelencia de los participantes.

119 Fue creada el 15 de agosto de 2000 mediante la Normativa sobre la Dirección, Gobierno y Administración del Poder Judicial, dictada por la Sala Plena del Tribunal Supremo de Justicia. (G.O. № 37.041 del 15-08-00). 


\section{Obstáculos para la aplicación del nuevo diseño constitucional ${ }^{120}$}

Pese a las bondades que, salvo excepciones como la señalada, ostenta la Constitución de 1999 en materia de justicia, desde ese mismo año se ha adelantado una ocupación política del poder judicial de efectos devastadores.

En tal sentido, el examen del marco normativo del Poder Judicial venezolano no puede desligarse de la actuación de la A samblea Nacional Constituyente de 1999. Tras una discutible decisión de la A samblea, mediante la cual se proclamó originaria, ésta se consideró facultada para dictar decretos que afectaran el funcionamiento de los poderes constituidos, lo cual implicó que el Poder Legislativo y el Poder Judicial vieran menoscabado su respectivo ámbito constitucional de atribuciones. Tal determinación de la Asamblea no era compatible con una sentencia de la Corte Suprema de Justicia que había ordenado suprimir de las bases comiciales sobre la Asamblea Nacional Constituyente, que serían sometidas a consulta popular, la alusión al carácter originario del poder que ostentaría dicho cuerpo, dado que éste quedaría sujeto, durante su funcionamiento, a la Constitución de 1961, entonces vigente, hasta la eventual aprobación de una nueva Constitución. Dicha Constitución preveía potestades del Congreso de la República y del Consejo de la Judicatura que resultarían quebrantadas por la actuación de esa A samblea, lo cual recibió posteriormente el aval de la propia Corte Suprema de Justicia.

En materia judicial fueron dictados decretos de emergencia y reestructuración judicial que permitieron acordar, sin base en criterios razonables, la inmediata suspensión de muchos jueces de la República. Se creó con carácter provisional una Comisión de Emergencia Judicial, luego sustituida por la Comisión de Funcionamiento y Reestructuración del Sistema Judicial. La provisionalidad de estas instancias ha sido desmentida por los hechos, pues esta última aún se desempeña como el órgano encargado de la función disciplinaria respecto de los jueces de la República, ante la falta de instauración de los tribunales disciplinarios previstos en la Constitución (art. 267 CRBV) y la ausencia del Código de Ética del Juez Venezolano o Jueza Venezolana también contemplado constitucionalmente. De ahí que la Sala Constitucional del Tribunal Supremo de Justicia haya declarado la inconstitucionalidad por omisión en que ha incurrido la Asamblea Nacional al no haber sancionado dicho Código (sentencia N 1.048 del 18 de mayo de 2006).

El desempeño de dicha Comisión de Funcionamiento y Reestructuración del Sistema Judicial con atribuciones en el campo disciplinario judicial no tenía fundamento alguno en la Constitución aprobada por el pueblo mediante referendo en diciembre de 1999, sino que se apoyaba en un decreto emanado de la A samblea Nacional Constituyente (Decreto mediante el cual se dicta el Régimen de Transición del Poder Público). Las Disposiciones Transitorias de la Constitución sólo prevén la actuación de tal Comisión en el sector de la defensa pública, hasta que sea dictada la ley orgánica

120 Tomado del informe presentado por Jesús M. Casal ante la Corte Interamericana de Derechos Humanos, en el caso A pitz Barbera y otros contra Venezuela. 
respectiva (Disposición Transitoria Cuarta, num. 5). No obstante, la Sala Constitucional del Tribunal Supremo de Justicia ha sostenido que los decretos de transición aprobados por la A samblea Nacional Constituyente son válidos y tienen rango constitucional, aunque su vigencia es provisional; pero la mayor fragilidad jurídica de este régimen de transición radica justamente en que, sobre todo en el campo de la justicia, el mismo tiende a perpetuarse. Pese a haber transcurrido ocho años desde la entrada en vigor de la Constitución de 1999, la citada Comisión sigue en funcionamiento, sin que para ello pueda invocarse una justificación aceptable.

La existencia de un régimen de transición en relación con la función disciplinaria judicial, que ha debido en todo caso ser incluido en las Disposiciones Transitorias de la Constitución y ofrecer garantías de independencia e imparcialidad, sólo podía justificarse hasta la elección de los integrantes e instalación de la A samblea Nacional, a la que cabía otorgar un tiempo prudencial para dictar las correspondientes normas disciplinarias y de organización judicial. Dicho lapso fue fijado por la propia Constitución, en lo que atañe a toda la legislación referida al sistema judicial: un año contado a partir de la instalación de la A samblea Nacional, que obviamente ha sido sobrepasado (Disposición Transitoria Cuarta, num. 5, CRBV).

La entronización de la transición se puso de manifiesto, igualmente, en el procedimiento seguido en diciembre de 2000 para la elección de los Magistrados del Tribunal Supremo de Justicia y de los titulares de los órganos del Poder Ciudadano (Fiscal General de la República, Defensor del Pueblo y Contralor General de la República), pues en esa ocasión la transición fue invocada para realizar tales designaciones sin cumplir todos los pasos constitucionalmente establecidos, a pesar de que la Asamblea Nacional ya estaba en funcionamiento y podía sancionar las normas legales necesarias para la estricta aplicación de los preceptos constitucionales. En lugar de hacerlo, dictó una ley especial o ad hoc que no se ceñía al procedimiento y principios de la Constitución, aduciendo como pretexto la ausencia de la legislación sobre el Tribunal Supremo de Justicia y sobre el Poder Ciudadano que ella misma estaba en el deber de sancionar.

De esta forma, el argumento de la transición constitucional ha sido uno de los obstáculos más serios para la efectiva vigencia de las previsiones constitucionales en el ámbito de la justicia. El contenido de las normas constitucionales sobre la materia es, en términos generales, adecuado y procura asegurar la independencia judicial, pero la excesiva prolongación de esa transición y la manera en que se ha abusado de la misma ha ido en detrimento de la fuerza normativa de la Constitución. Algunos episodios institucionales hacen pensar que la transición se alimenta de sí misma y ha generado círculos viciosos de autojustificación y fractura jurídica, como ocurrió con motivo de la elección de Magistrados y de los titulares de los órganos del Poder Ciudadano en el año 2000. La fractura jurídica también se produjo, aunque esta vez sin acudir a la transición como pretexto, a raíz de la ampliación, con móviles indudablemente políticos, del número de M agistrados del Máximo Tribunal, acordada por la Ley Orgánica del Tribunal Supremo de Justicia (2004).

Igualmente, es digna de mención la decisión de la Sala Constitucional del Tribunal Supremo de Justicia $N^{\circ} 1.057$ del 1 de junio de 2005, por la cual, al admitir un recurso 
de inconstitucionalidad por omisión interpuesto contra la Asamblea Nacional por no haber sido sancionado el Código de Ética del Juez Venezolano o Jueza Venezolana, dicha Sala procedió a renovar los integrantes de la Comisión de Funcionamiento y Reestructuración del Sistema Judicial, que habían sido designados por la Asamblea Nacional Constituyente "hasta el funcionamiento efectivo de la Dirección Ejecutiva de la M agistratura, de los Tribunales Disciplinarios y del Sistema A utónomo de la Defensa Publica" (art. 28 del Decreto sobre el Régimen de Transición del Poder Público). En lo que concierne al ejercicio de la función disciplinaria judicial, lo relevante es que la ausencia de los tribunales disciplinarios no fue obstáculo para que la Sala Constitucional resolviera reemplazar a los integrantes de dicho cuerpo, sin dar razón alguna referida al desempeño de quienes ocupaban tales cargos por decisión de la Asamblea Nacional Constituyente, lo que conduce a sostener que los integrantes de tal Comisión carecían de la estabilidad necesaria para ejercer la delicada función de pronunciarse sobre las posibles faltas disciplinarias de los jueces de la República. Con posterioridad a esa primera renovación, la misma Sala Constitucional ha efectuado otras designaciones, en virtud de la renuncia de los titulares de tales cargos.

El soslayamiento de la plena vigencia de la Constitución derivado de la utilización y el abuso del régimen de transición de los poderes públicos ha repercutido negativamente en la independencia judicial, porque la inmensa mayoría de los jueces de la República carecieron durante un largo periodo, dentro del cual se suscitó el caso sobre el cual versa esta opinión jurídica, de estabilidad en sus cargos y su nombramiento no se originó, en ese mismo lapso, en procedimientos transparentes que ofrecieran objetividad en cuanto a los criterios de selección. Muchas de las remociones (encubiertas) entonces adoptadas estuvieron probablemente relacionadas con móviles políticos. ${ }^{121}$

Un aspecto del régimen del Poder Judicial que requiere de una exposición particular es el relativo al nombramiento y remoción de los jueces. Aquí ha jugado un papel no despreciable, como dijimos, la llamada transición constitucional, aunque también han confluido otros factores.

En lo que atañe al nombramiento de los jueces, formalmente corresponde al Tribunal Supremo de Justicia, así como su juramentación (art. 255 CRBV). Antes de tal nombramiento la selección de los jueces se ha realizado siguiendo fundamentalmente dos vías diferentes. Si se ha organizado un concurso para el ingreso, la persona o personas favorecidas por el concurso se hacen merecedoras de la designación. M ientras los concursos no sean efectuados, suele acudirse a nombramientos con carácter temporal o provisorio. No obstante, el tratamiento de esta materia no ha sido uniforme a lo largo de los ocho años de vigencia de la Constitución.

En una primera etapa, que va desde la entrada en vigor de la Constitución hasta el año 2002, se programaron y llevaron a cabo concursos de oposición para el ingreso en

121 Vid., entre otros, los Informes Anuales de PROVEA sobre la Situación de los derechos humanos en Venezuela correspondientes a octubre 2003-septiembre 2004, pp. 375 y ss., y a octubre 2004-septiembre 2005, pp. 351 y ss., así como el Informe de Human Rights Watch, Manipulando el Estado de Derecho: Independencia del Poder Judicial amenazada en Venezuela, Cap. V, 2004. 
la carrera judicial, con base en normas dictadas por la mencionada Comisión de Funcionamiento y Reestructuración del Sistema Judicial (Normas de Evaluación y Concursos de Oposición para el Ingreso y Permanencia en el Poder Judicial). El régimen aprobado en estas normas se componía de dos elementos: la evaluación de los jueces y el concurso. Los jueces de la República debían ser evaluados en su desempeño, conforme a criterios fijados en tales normas. Si el resultado de la evaluación era positivo, el juez era ratificado en su cargo, cuando se tratara de jueces titulares que ya hubieran concursado durante la vigencia de la Constitución anterior; cuando el juez tuviera carácter provisorio, por no haber concursado, la evaluación positiva lo habilitaba para participar en el concurso. Los concursos de oposición también estaban regulados en dichas normas, y fueron organizados con participación de diversos sectores del país, incluyendo a Profesores de Universidades públicas y privadas.

Desde el año 2003 tales concursos fueron suspendidos, lo que frenó el proceso de regularización de la situación de la judicatura que, de manera lenta pero aceptable a la luz de los principios constitucionales, se adelantaba, lo cual condujo a que durante varios años se mantuviera en el país un porcentaje cercano al $80 \%$ de jueces en calidad de provisorios, tal como ocurría al momento de presentarse los hechos objeto de este procedimiento. El carácter provisorio (o temporal) de los jueces implica que carecen de estabilidad en sus cargos y que para separarlos de los mismos no es imprescindible la apertura de un procedimiento previo que garantice el derecho a la defensa, como tampoco lo es comprobar que hayan incurrido en falta disciplinaria. Se impuso la práctica, amparada por la Comisión Judicial del Tribunal Supremo de Justicia, de dirigir un oficio, a menudo por vía de fax, a los jueces, indicando que su nombramiento había quedado "sin efecto". Esta libertad para pronunciarse sobre la remoción del juez provisorio también imperaba para su designación.

Desde mediados del 2005 el Tribunal Supremo de Justicia procuró reiniciar los concursos para el ingreso al Poder Judicial, rediseñándolos y sometiéndolos a nuevas normas. Varios sectores han denunciado que este proceso no ha estado acompañado de la participación ciudadana exigida por la Constitución (art. 255 CRBV) ni se ha distinguido por la debida transparencia y su apego a las normas constitucionales. ${ }^{122}$ Es discutible, igualmente, que los nuevos procedimientos de ingreso, tal como han sido regulados y aplicados, representen verdaderos concursos de oposición públicos, de acuerdo con lo requerido constitucionalmente, ya que la posibilidad de concurrir estuvo circunscrita, en relación con un elevado número de tribunales, a los actuales jueces, generalmente provisorios - cuya forma de ingreso ya destacamos-, asemejándose los llamados concursos a un procedimiento de evaluación y confirmación del juez en su cargo. En todo caso, esta vía de ing reso ha sido implementada con cierta celeridad, lo cual se ha traducido en una significativa reducción del número de jueces provisorios, sin que ello signifique, por las razones señaladas, que los problemas relativos a la reducida independencia del Poder Judicial y a la limitada autonomía del juez hayan sido atendidos adecuadamente.

122 Vid., entre otros, los Informes A nuales de PROVEA sobre la Situación de los derechos humanos en Venezuela correspondientes a octubre 2005-septiembre 2006, pp. 267 y ss., y a octubre 2006-septiembre 2007, pp. 273-274, así como el Informe de la Fundación Konrad Adenauer, Rule of Law 2006, pp. 297 y ss. 
En lo que respecta a la destitución o remoción de los jueces, la Constitución exige el establecimiento de un orden jurisdiccional especial, la jurisdicción disciplinaria judicial. En ausencia de ésta, y con base en el régimen de transición, esas funciones disciplinarias han sido asumidas por la Comisión de Funcionamiento y Reestructuración del Sistema Judicial. No obstante, como ya apuntamos, en paralelo a esta forma de sanción y eventual separación de un juez de su cargo, se ha acudido a la vía expedita, e inconstitucional (arts. 255 y 49 CRBV), de dejar sin efecto la designación de los jueces provisorios, mediante decisiones carentes de motivación, adoptadas generalmente por la Comisión Judicial del Tribunal Supremo de Justicia, que carece de competencia en materia disciplinaria judicial. Ello ha conducido a una situación de enorme vulnerabilidad de los jueces frente a presiones de diversa índole. Esta vulnerabilidad ha alcanzado a los Magistrados del Tribunal Supremo de Justicia, como lo demuestra la remoción del M agistrado Franklin A rrieche mediante el subterfugio de la declaratoria de la nulidad de su designación, la cual respondió a las críticas que la sentencia del Tribunal Sup remo de Justicia relativa a los acontecimientos del 11 de abril de 2002, de la que él fue ponente, suscitó en las más altas esferas de los Poderes Ejecutivo y Legislativo.

\section{DERECHOS FUNDAMENTALES}

\section{A. Consideraciones generales}

En el periodo señalado se ha producido una importante evolución en materia de derechos fundamentales (o derechos humanos). El marco constitucional vigente en 1975 establecía una generosa declaración de derechos y preveía variados mecanismos para su protección. La declaración partía del reconocimiento de la libertad como principio y admitía la introducción de restricciones cuando existiese una justificación (art. 43); además, el catálogo de derechos se caracterizaba por su diversidad, pues comprendía tanto a derechos clásicos de libertad como a derechos sociales. A ello se sumaba la apertura de ese catálogo constitucional a derechos inherentes a la persona no previstos en el texto constitucional (art. 50).

Pero la amplitud de esta regulación constitucional no siempre se vio reflejada en la praxis de las autoridades de las distintas ramas del poder público. La década dictatorial que culminó en 1958 detuvo el desarrollo de la conciencia democrática y de respeto a los derechos humanos que podía madurar con apoyo en la Constitución de 1947 y consolidó prácticas policiales represivas. A dicionalmente, la tesis del carácter meramente programático de las normas constitucionales hasta que recibieran regulación legislativa dejó en vilo parte de la Constitución.

Veremos cómo esta situación tendió a cambiar una vez que se admitió la operatividad del amparo constitucional y de los demás derechos o garantías constitucionales. A partir de allí se abre una etapa en la cual el poder judicial se compromete, aunque parcialmente, con la garantía de la vigencia de los derechos fundamentales. Ello permitió progresos jurisprudenciales que en buena medida desembocaron en la formulación vanguardista de la Constitución de 1999, en la cual también influyó la actuación de las ONGs, que desde finales de la década de los ochenta se hicieron activas en el escenario público nacional. 


\section{B. La tesis del carácter programático de las normas constitucionales y la limitada significación jurídica de los derechos y garantías constitucionales}

En la década de los setenta encontró eco jurisprudencial la tesis de que las normas constitucionales o algunas de ellas tenían naturaleza programática, por lo que adquirían operatividad jurídica cuando eran desarrolladas legislativamente. Esto era expresión de una conciencia jurídica bastante extendida que no reconocía todas las implicaciones del carácter normativo de la Constitución y, particularmente, de su parte dogmática.

Las deficiencias no se agotaban en el condicionamiento de la fuerza normativa de los derechos aún no legislados, sino que comprendía a aquellos que lograron alcanzar regulación legal. Una somera observación de la jurisprudencia relativa al control concentrado de constitucionalidad de las leyes revela que la mayoría de las sentencias dictadas se referían a la protección de la parte orgánica de la Constitución. En lo que atañe al control difuso de la constitucionalidad, éste era ejercido raramente. Habría que esperar al despliegue de la eficacia jurídica del amparo para que los derechos constitucionalmente asegurados mostraran completamente sus potencialidades como parámetro para el control de los actos del poder público.

\section{El amparo constitucional y la operatividad de los derechos}

En virtud de una evolución que se explicará luego al examinar los mecanismos de protección constitucional, en 1983 la Corte Suprema de Justicia aceptó la operatividad del amparo constitucional y con ello catapultó un proceso que se venía siendo impulsado por los jueces de instancia. La sentencia del máximo tribunal permitía además concluir que dicha operatividad era predicable de todos los derechos y garantías constitucionales. El creciente uso del amparo que siguió a ese pronunciamiento generó complicaciones procesales concernientes a la forma de relacionar este instrumento con el resto del ordenamiento procesal, pero tuvo el efecto positivo de propiciar la presencia de los derechos en todos los estrados judiciales y de favorecer un razonamiento y una estrategia jurídica apoyada en los mismos, que repercutiría en la formación, en el lenguaje y en la mentalidad jurídica.

La explosión del amparo despertó el interés por el Derecho Constitucional y, en particular, por esta faceta de la Constitución que estaba siendo reconocida y que trascendía de la reflexión o de la discusión política para penetrar en el foro y en la dinámica judicial. Por esta vía también se incorporaron aportes doctrinarios provenientes de otros ordenamientos jurídicos, siendo dignas de mención contribuciones procedentes del Derecho español, el cual se hallaba en una fase de descubrimiento de la fuerza normativa de la Constitución que ofrecía múltiples referencias para el Derecho venezolano. En la misma dirección apuntó la ratificación por Venezuela de los principales tratados internacionales sobre derechos humanos. 


\section{Zonas de penumbra e iluminación jurisprudencial}

El retraso en la aceptación de las implicaciones normativas de la Constitución hizo posible la pervivencia de zonas del ordenamiento jurídico en las que continuaban en vigor reglas que eran reflejo de una concepción autoritaria sobre las relaciones entre el poder y la libertad, no cónsonas con el espíritu democrático y la garantía de los derechos de la Constitución de 1961. Muestra de ello era la normativa relativa al derecho a la libertad personal. La legislación vigente permitía las sanciones administrativas privativas de la libertad, autorizaba detenciones policiales insertas en el proceso penal de larga duración y sustentaba, según la opinión oficial, una ley preconstitucional en la que se preveía la privación administrativa de libertad de personas que fuesen consideradas como vagos o maleantes, con base en criterios de peligrosidad predelictual.

Hubo que esperar a 1997 para que la Corte Suprema de Justicia, después de 12 años desde la interposición del recurso, se dispusiera a revisar con rigor la compatibilidad de estas últimas normas con la Constitución. La declaratoria de la inconstitucionalidad de la Ley sobre Vagos y Maleantes marcó un hito en la evolución de la jurisprudencia relativa a los derechos constitucionales, pues se tradujo en la expulsión del ordenamiento de esta ley autoritaria y sentó las bases teóricas para la revisión de otras medidas administrativas similares. A demás, consolidó una corriente doctrinal y jurisprudencial que propugnaba la constitucionalización de los derechos humanos, en cuyo respaldo se invocaba el artículo 50 de la Constitución, que contemplaba la protección de derechos inherentes a la persona no previstos en el texto constitucional, entre los cuales debían encontrarse los derechos consagrados en tratados internacionales sobre derechos humanos ratificados por Venezuela. Esta tendencia alcanzaría realización en la Constitución de 1999.

\section{E. La suspensión o restricción de garantías constitucionales}

Una figura que jugó un papel en la desvalorización de la Constitución en el periodo examinado fue la de la suspensión o restricción de derechos o garantías constitucionales. Desde el mismo día de la promulgación de la Constitución de 1961 se dictó una suspensión de garantías individuales que amenazaba el respeto debido a estos derechos y facilitaba la persecución política. Luego fueron restablecidas algunas de ellas, pero la libertad económica permaneció restringida hasta 1991, con lo cual el Ejecutivo Nacional podía dictar normas con fuerza de ley sobre los ámbitos socioeconómicos más diversos, afectando el régimen constitucional general de los derechos así como las facultades del Congreso de la República.

El episodio más lamentable en cuanto al abuso del mecanismo citado fue la suspensión de garantías decretada en 1989 para hacer frente al desbordamiento de saqueos populares de comercios acaecido el 27-28 de febrero de ese año. Bajo la tesis de que tal figura suspendía los derechos señalados en el decreto presidencial, los jueces se abstuvieron de tramitar acciones de amparo de la libertad física (habeas corpus) interpuestas por personas arbitrariamente detenidas, con lo cual los jueces 
concurrieron en la violación de derechos humanos perpetrada durante esos días y los inmediatamente posteriores, consistentes en una represión brutal que no fue luego investigada adecuadamente por el Estado y que supondría para Venezuela la condena del sistema interamericano de protección de los derechos humanos.

Durante suspensiones de garantías posteriores el poder judicial abandonó parcialmente su pasividad al declarar la Corte Suprema de Justicia su competencia para conocer de acciones de inconstitucionalidad contra decretos que impongan un estado de excepción, pero volvió a abdicar de su función tutelar de los derechos al rechazar acciones de amparo bajo otra argumentación igualmente errónea, en virtud de la cual durante los estados de excepción no se suspendían los derechos sino las garantías, entre las que se encuentra nada más y nada menos que el amparo constitucional. La Constitución de 1999 afortunadamente ha superado esta equivocada comprensión de los estados de excepción, apoyada en la doctrina y en aportes de la Corte Interamericana de Derechos Humanos.

\section{F. Los derechos humanos y su contribución al desarrollo institucional}

Conviene aludir particularmente a la importancia de la protección internacional de los derechos humanos para el desarrollo institucional venezolano. La ratificación por Venezuela de la Convención Americana sobre Derechos Humanos (1977), del Pacto Internacional de Derechos Civiles y Políticos y de su Protocolo Facultativo y del Pacto Internacional de Derechos Económicos, Sociales y Culturales (1978), así como el reconocimiento por Venezuela de la competencia contenciosa de la Corte Interamericana de Derechos Humanos (1981) favorecieron el despliegue de las implicaciones jurídicas de los derechos fundamentales en el orden interno. Los derechos humanos, en su dimensión jurídica-internacional, acompañaron las iniciativas jurisprudenciales dirigidas a hacer operativo el amparo aun en ausencia de una ley de desarrollo; respaldaron la creación de organizaciones no gubernamentales destinadas a su promoción y defensa y estuvieron presentes en la reflexión pública sobre situaciones fácticas y normativas que debían ser superadas, tal como ya se expuso en relación con algunos ámbitos. El uso del sistema interamericano de protección de los derechos humanos en algunos casos, y la sola perspectiva de poder hacerlo, confirió al tratamiento del tema una significación hasta entonces desconocida.

\section{G. La Constitución de 1999 y el devenir posterior}

La Constitución de 1999 introdujo, como ya se adelantó, importantes avances en materia de derechos humanos. Se consagró el rango constitucional de los tratados sobre derechos humanos ratificados por Venezuela, así como el criterio in dubio pro homine. Se constitucionalizaron principios y obligaciones provenientes del Derecho Internacional de los Derechos Humanos, como los principios de interdependencia e indivisibilidad de los derechos y los deberes de respeto y garantía. Se circunscriben los poderes de las autoridades durante estad os de excepción y se amplían los respec- 
tivos controles. El catálogo de derechos es además generoso, sobre todo en el ámbito del constitucionalismo social, y mantiene la apertura a los derechos inherentes a la persona no enunciados expresamente en la Constitución.

Pero las bondades del texto constitucional no han estado secundadas de una actuación consecuente de los poderes públicos. En casi todos los ámbitos el legislador ha incurrido en mora, particularmente en relación con derechos de tipo social o prestacional. En lo que atañe a los derechos civiles y políticos, la jurisprudencia constitucional ha sido restrictiva, incluso cuando han entrado en juego tratados internacionales de derechos humanos o decisiones de los órganos internacionales encargados de interpretarlos. La jerarquía constitucional de estos tratados ha sido mediatizada por la jurisprudencia constitucional. A lo anterior se suma la discriminación política que ha afectado a muchos venezolanos y que se ha traducido en medidas de persecución y en la tolerancia de situaciones que ponen en peligro el desempeño de comunicadores sociales o defensores de derechos humanos. ${ }^{123}$

\section{LOS PARTIDOS POLÍTICOS}

\section{A. La democracia de partidos (1970-1990)}

El estudio de los partidos políticos en el período de 1975 hasta el 2005 definitivamente revela un profundo cambio en apenas cuatro décadas. La Constitución de 1961 establecía el derecho a asociarse bajo la forma política de los partidos, con la previsión de que se trataba de métodos democráticos en la vida política nacional; sin embargo, no dispuso nada sobre la organización de los mismos delegando tal atribución en el legislador. ${ }^{124}$

No fue sino hasta el 30 de abril de 1965 cuando se publicó en Gaceta Oficial la Ley de Partidos Políticos y Manifestaciones Públicas, en la cual se definió a los partidos como agrupaciones de carácter permanente cuyos miembros convienen en asociarse para participar, por medios lícitos en la vida política del país.

Asimismo, en dicha Ley se señalaba el compromiso por parte de los partidos políticos de perseguir sus objetivos a través de métodos democráticos, de igual manera se aseguraba que la participación fuese "directa o representativa en el gobierno del partido".

Para 1975, los partidos Acción Democrática (AD) y Comité de Organización Política Electoral Independiente (COPEI) se han convertido en los principales partidos políticos venezolanos, que se gestaron y crecieron durante la décadas de los 40,50 y 60 . A mbos partidos, con predominio de AD en el escenario político previo a los setenta, con el

123 Para una relación detallada de violaciones a derechos humanos vid. los informes de PROVEA comprendidos entre el 2000 y el 2005.

124 Art. 114, Constitución 1961. 
Trienio Adeco después del derrocamiento de Isaías Medina Angarita, la lucha en la clandestinidad durante los diez años de la dictadura de Pérez Jiménez y finalmente el "Pacto de Punto Fijo", fueron los contendores más importantes en las disputas electorales sucesivas a 1963. En las elecciones del 63 resultó electo el candidato de AD Raúl Leoni, con una diferencia del $12 \%$ sobre Rafael Caldera, candidato de COPEI.

Es destacable que, aun existiendo otros partidos políticos de vieja data como lo era el partido Unión Republicana Democrática (URD), el cual ya para los años 60 estaba relegado al tercer puesto en las posiciones electorales, y existiendo en la palestra política otros partidos de filiación adeca, era para entonces claro que serían AD y COPEl los partidos que vendrían a definir las elecciones a posteriori, sucesos que consolidaron un sistema bipartidista.

En los años sucesivos las presidencias fueron alternadas entre candidatos de estos dos partidos, lo cual arrojó el siguiente escenario: ${ }^{125}$

\begin{tabular}{|l|c|c|c|c|c|}
\hline \multirow{2}{*}{ Partido } & \multicolumn{5}{|c|}{ años electorales y porcentajes obtenidos } \\
\cline { 2 - 6 } & 1968 & 1973 & 1978 & 1983 & 1988 \\
\hline AD & 27.5 & 44.4 & 43.3 & 56.7 & 52.9 \\
Presidente & $\mathbf{2 5 . 6}$ & $\mathbf{4 2 . 8}$ & 39.7 & $\mathbf{4 9 . 9}$ & $\mathbf{4 3 . 2 4}$ \\
Congreso & 28.7 & 33.8 & 46.7 & 34.5 & 40.2 \\
\hline COPEI & 24.0 & 30.2 & $\mathbf{3 9 . 8}$ & 28.7 & 31.3 \\
Presidente & & & &
\end{tabular}

Los presidentes para esas fechas fueron:

- Rafael Caldera (COPEI)

1969-1974

- Carlos Andrés Pérez (AD)

1974-1979

- Luis Herrera Campins (COPEI) 1979-1984

- Jaime Lusinchi (AD)

1984-1989

- Carlos Andrés Pérez (AD)

1989-1993

El bipartidismo originó que durante esos años $A D$ y COPEl no sólo ocuparan los principales puestos de gobierno en el país, sino que sus militantes coparon, por lo menos hasta la década de los 90 , la mayor parte del servicio público y diplomático venezolano. Asimismo, la penetración existente en esas décadas por parte de AD y

${ }_{125}$ Según datos extraídos del cuaderno $N^{\circ} 36$ del Curso de Formación Sociopolítica de la Fundación Centro Gumilla, titulado "Los Partidos Políticos en Venezuela II. Los partidos modernos" de Samuel Pérez, p. 85. 
COPEl en los distintos sectores, permitió a esos partidos proveer de su seno los miembros de sindicatos y de las organizaciones y gremios que hacían vida en el país, surgiendo así el fenómeno que fue calificado como la partidocracia.

\section{B. La crisis de la democracia de partidos (1990-1999)}

En las elecciones de 1988, el triunfo electoral correspondió nuevamente a $A D$, pese a los rasgos que caracterizaron el gobierno presidido por Jaime Lusinchi, al cual se atribuye un incremento de la burocracia, del centralismo, ${ }^{126}$ de los altos niveles de corrupción, aunado al hecho de que sus políticas económicas sólo generaron un incremento de la inflación y no fueron sustentables en el tiempo.

La victoria electoral de AD puede explicarse por otros factores, como lo afirma Samuel Pérez; ${ }^{127}$ entre sus principales causas indiscutibles se encuentra el carisma de Carlos Andrés Pérez, el efecto transitorio de la política populista emprendida por Jaime Lusinchi, el uso de los recursos de la oficina central de información para desplegar una campaña comunicacional con un nivel de profesionalismo, intensidad y calidad técnica nunca antes vistos en Venezuela y la torpe oposición desarrollada por CO PEl y el MAS.

Sobre este escenario político de las elecciones de 1988, cuando AD y COPEI acapararon alrededor del $93 \%$ de los votos, se vivía aparentemente la apoteosis del bipartidismo; sin embargo, se estaba gestando un cambio en la masa electoral, suscitado por el descontento general en el desarrollo de la democracia de partidos, lo cual se evidenció, sin causar alarma para ese entonces, en los niveles de abstención que se estaban registrando en los últimos eventos electorales, que no tenían precedentes.

Tal descontento encontraría su cauce más adelante. El gobierno de Carlos Andrés Pérez y sus ajustes económicos con influencias neoliberales no tuvieron aceptación en la población, dándose una revuelta popular el 27 de febrero de 1989 y luego dos intentonas de golpe de Estado. Posteriormente se produjo el enjuiciamiento del Presidente y su separación del cargo.

A pesar de la elección consensuada del Presidente de transición entre AD y COPEI (Ramón J. Velásquez), con el ánimo de sostener un clima de tranquilidad hasta llegar a las elecciones de 1993, lo que se desataría después sería la crisis del bipartidismo, lo cual dio apertura a otros partidos políticos que habían carecido de trascendencia polí-

${ }^{126}$ Cabe destacar sobre el centralismo que Jaime Lusinchi fue quien creó la Comisión Presidencial para la Reforma del Estado (COPRE), encargada de estudiar las reformas necesarias para la conformación de un sistema político más participativo y una administración más eficiente, no obstante, este mismo personaje le dio la espalda a las propuestas, dejadas en el tintero por esta Comisión y que verían su salida una vez terminado su período.

127 En "Los partidos políticos en Venezuela II. Los partidos modernos", cuaderno 36, Caracas, Fundación Centro Gumilla, 1996, p. 33. 
tica en pasadas elecciones y obtuvieron puestos dentro del Congreso. Tal es el caso del Movimiento al Socialismo (MAS) y de la Causa Radical (Causa R). ${ }^{128}$

A simismo, un importante hecho lo constituyó la crisis presentada dentro del seno de COPEI, iniciada en las elecciones de 1983, cuando la ventaja adeca fue de 22 puntos porcentuales de diferencia, crisis que tuvo su punto más álgido en 1993, cuando su líder Rafael Caldera abandona el partido para fundar una alianza electoral denominada Convergencia Nacional. A mbos acontecimientos redujeron la participación de COPEl en los sucesivos procesos electorales.

El Congreso para 1994 quedó constituido por cinco principales partidos: AD, COPEI, Causa R, Convergencia y el MAS, rompiéndose con el viejo esquema del bipartidismo.

No podemos dejar de resaltar en estas notas otro factor determinante, que pronto entraría a jugar un papel en el escenario político, para dar otra estocada al sistema bipartidista: la introducción de las elecciones directas de gobernadores y alcaldes en 1989. Esto condujo, más adelante, a que nuevos líderes con gestiones exitosas entraran en la palestra pública nacional, sin necesidad de contar con la venia de la dirigencia de los partidos tradicionales, como fue el caso en Carabobo de los Römer y de Proyecto Venezuela.

Por otra parte, hay que hacer alusión a la idea militarista con la cual se engolosinó el electorado, después de las intentonas golpistas en el período presidencial de Carlos Andrés Pérez, abriendo una brecha de nuevo a la participación de los militares en la vida política, la cual había sido desterrada con la Constitución de 1961.

En este contexto se inscribe el Movimiento Bolivariano Revolucionario, que se denominó el MBR-200 y lanzó al espacio político al Teniente Coronel Hugo Chávez Frías, como el líder de ese movimiento y del cambio que se gestaba dentro de las tropas militares. Adquirió rápidamente un auge de popularidad añadido a la crisis de los partidos y de la incredulidad hacia el sistema democrático como estaba concebido hasta entonces por los venezolanos.

La falta de madurez de la clase política para asumir los cambios reclamados por la población electoral venezolana, y la idea mesiánica que ha perseguido a los países del área, permitieron avanzar a la nueva ideología propugnada por el M BR-200, que en 1997 muda su nombre a M ovimiento V República, para deslastrarse del calificativo de movimiento insurreccional y poder participar en las elecciones de 1998, para el Congreso y la Presidencia.

Es así como los escrutinios arrojaron los siguientes resultados de representantes por agrupación política en las elecciones del 8 de noviembre de 1998, concernientes a la elección de senadores y diputados del Congreso y diputados a asambleas legislativas: ${ }^{129}$

128 En las elecciones de 1993, el MAS obtuvo en el Congreso un porcentaje de 10.6\%, la Causa R 19.6\% y Convergencia $12.4 \%$.

129 Datos de la página Oficial del Órgano Electoral: www.cne.gov.ve 


\begin{tabular}{|l|r|}
\hline Partidos & Totales \\
\hline AD & 226 \\
MVR & 133 \\
COPEI & 101 \\
MAS & 61 \\
PRVZL & 43 \\
PPT & 22 \\
LCR & 18 \\
Convergencia & 15 \\
\hline
\end{tabular}

Respecto de las elecciones presidenciales celebradas en diciembre del mismo año, los datos fueron los siguientes: ${ }^{130}$

\begin{tabular}{|l|l|c|}
\hline Candidato & Agrupaciones Políticas & $\begin{array}{c}\text { Porcentajes de } \\
\text { votos válidos }\end{array}$ \\
\hline Hugo Chávez Frías & $\begin{array}{l}\text { MVR, MAS, PPT, IPCN, PCV, } \\
\text { GE, MEP, SI, AA }\end{array}$ & 62.46 \\
\hline Enrique Salas Römer & PRVZL, AD, COPEI, PQAC & 31.48 \\
\hline Irene Sáez Conde & IRENE, FD, LA LLAVE, INCVF & 4.60 \\
\hline Miguel Rodríguez & APERTURA & 0.70 \\
\hline Luis A Ifaro Ucero & $\begin{array}{l}\text { ORA, URD, RENACE, VU, ICC, } \\
\text { FIN, ONDA }\end{array}$ & 0.38 \\
\hline
\end{tabular}

C. La Constitución de 1999: La sustitución de los partidos políticos por asociaciones con fines políticos

En 1999 es promulgada la Constitución de la República Bolivariana de Venezuela, que contiene en su artículo 67 la regulación a los partidos políticos. Esta nueva Cartas Magna quiso trazar rasgos generales con rango constitucional en lo concerniente a la organización de los partidos políticos, que en el pasado se había entregado al legislador; sin embargo, no se refirió a ellos como partidos políticos como "asociaciones con fines políticos", eliminándose así la referencia expresa constitucional que hacía la Constitución de 1961.

130 Ídem. 
Los puntos centrales que se prevén en el artículo 67 son:

- M étodos democráticos de organización, funcionamiento y dirección de tales asociaciones.

- Elección de los integrantes de la dirección y de los candidatos con la participación de sus miembros.

- Supresión del financiamiento del Estado.

- Prohibición de contratar con entidades del sector público.

Esta regulación pretendía ser una respuesta al régimen de control de la democracia por las cúpulas de los principales partidos que había sido denunciado. En relación con el financiamiento de los partidos la jurisprudencia ha aclarado el alcance de la prohibición constitucional. La Sala Constitucional interpretó la norma correspondiente en sentencia $\mathrm{N}^{\circ} 780$, de fecha 8 de mayo de 2008, con ocasión del recurso interpuesto por los partidos políticos PPT y PODEMOS; en dicha sentencia se concluyó que:

“Por tanto, el contenido y alcance de la norma contenida en el artículo 67 de la Constitución de la República Bolivariana de Venezuela, respecto a la proscripción de aportar fondos públicos a las asociaciones políticas, no limita que en el marco del proceso electoral y como gasto inherente a una fase esencial del mismo, el Estado (de acuerdo con el principio de legalidad presupuestaria y observando el principio de reserva legal que impera en materia de elecciones, según dispone el artículo 156.32 de la Carta Fundamental), destine fondos con el objeto de financiar el desarrollo de las campañas electorales, de los partidos y asociaciones políticas inscritos ante el ente comicial, en el contexto del pluralismo político como elemento esencial de la democracia participativa y racional, pero que en todo caso, requiere ex profeso, de regulación normativa por parte de la Asamblea Nacional, porque en esto descansa el ejercicio de la reserva legal".

\section{Chavismo vs. Oposición}

Con la entrada de Hugo Chávez en la Presidencia de la República empieza a dibujarse un cambio en los partidos políticos venezolanos, dada la fuerte influencia del Presidente en los distintos sectores y las reformas que inició una vez que asumió el cargo. Reformas que no fueron aceptadas por la población de la clase media y alta venezolana, ni por los partidos políticos ajenos al gobierno, entre los que se encontraban algunos de vieja data (AD, COPEI, MAS, CAUSA R) y otros que surgieron como abanderados del cambio frente a los viejos partidos, con gente joven, dentro de la misma oposición venezolana, como fue el caso del Movimiento Primero Justicia.

Así, los partidos que no se asimilaban a las ideas de transformación del gobierno, experimentaron un aislamiento en la escena política. Ello convergió en la formación de un bloque oposicionista al gobierno presidencial de Hugo Chávez Frías, quien tenía los más altos índices de popularidad, lo que le permitió realizar la Constituyente, desmantelar el viejo Congreso y llamar a nuevas elecciones de diputados y de presidente.

En las elecciones del año 2000, el partido dominante que ganó las elecciones de gobernadores y de disputados a la Asamblea Nacional fue el MVR y otros partidos 
seguidores del chavismo, obteniendo 16 gobernaciones de los 23 estados y 44.38 puntos porcentuales de los votos válidos en el órgano deliberante.

A simismo, para las elecciones regionales del año 2004 se repitió la tendencia favorecedora a la línea oficialista, esta vez catapultada por el abstencionismo opositor, arrojando como resultado 20 estados con gobernadores chavistas y sólo dos de oposición, que recibieron el apoyo de los principales partidos como AD, COPEI, PRVZL, MPJ, LA CAUSA R, MAS entre otros.

La alta polarización venezolana, entre dos bandos, ha traído como consecuencia que las elecciones no se establezcan como pugna entre partidos, sino entre oficialismo y oposición, reuniendo el partido de gobierno a los solidarios del chavismo, como fue PPT, PODEMOS, PCV entre sus principales.

Los resultados electorales propiciaron la unión de la oposición, para ejercer un cauce de acción común de disidencia al gobierno nacional. En esta línea la oposición definió dos acciones de unidad: 1. Retirar en conjunto sus candidaturas para las elecciones parlamentarias de 2005, como protesta ante la desconfianza en el organismo electoral, lo cual condujo a que la A samblea Nacional estuviera compuesta en su totalidad por organizaciones con fines políticos que apoyan al gobierno bolivariano; 2 . Respaldar unánimemente la candidatura presidencial de Manuel Rosales para las elecciones 2006.

Dichas elecciones arrojaron una escisión en dos sectores, pero ahora no representados por dos partidos, sino por dos tendencias, que ha caracterizado la década del 2000 , en virtud de la intolerancia y fricción constante entre gobierno y oposición, fenómeno que ha obligado a la unidad de los partidos oficialistas, así como la de los partidos contrarios al Presidente.

En este marco, Hugo Chávez Frías obtiene de nuevo la victoria en el 2006, con el $62,84 \%$ frente a Manuel Rosales, quien sólo logra acumular el 36,9\%.

Sin embargo, el bipartidismo entre estas dos tendencias "oficialismo vs. oposición", también asoma visos de crisis hacia el fututo, tal y como lo presagiaron los niveles de abstención que crecían en la democracia de partidos durante la hegemonía de AD y COPEI.

Por parte del oficialismo, la crisis se manifiesta en la inconformidad de partidos cercanos al movimiento chavista, a ser unificados en un sólo partido denominado Partido Socialista Unido de Venezuela (PSUV), por la propia iniciativa del Presidente de la República en el año 2007. Los partidos PCV, PPT y PODEM OS, se negaron a ser fusionados en el partido único, pero este último tomó una posición más radical y culminó separándose de la coalición oficialista, iniciando un coqueteo con la oposición. A simismo, se evidenció una fractura del dominio chavista con la negación de la población venezolana en asumir una reforma constitucional que era bandera del oficialismo.

Situación semejante enfrenta la oposición venezolana, al presentar crisis de unidad para elegir candidatos únicos en las próximas elecciones regionales, y no subestimar 
el hecho, de la necesidad de los partidos contrarios al gobierno de buscar nuevos personajes que le den legitimidad frente al electorado, cansado de las pugnas partidistas dentro su seno, que determinen la voluntad de asistir a las urnas, como es el caso de asistirse del recientemente levantado Moviendo Estudiantil.

\section{LOS MECANISM OS DE DEFENSA DE LA CONSTITUCIÓN}

\section{A. Consideraciones generales}

Ya en 1975 Venezuela poseía un sistema de defensa de la Constitución de carácter básicamente judicial, que se distinguía por la naturaleza mixta o integral del sistema de justicia constitucional. Estos rasgos están presentes en nuestro ordenamiento desde el siglo XIX, pero bajo las coordenadas temporales en que nos situamos basta con indicar que se hallaban plasmados en la Constitución entonces vigente, de 1961, y en el Código de Procedimiento Civil en lo concerniente al control difuso de la constitucionalidad de las leyes.

Junto a los mecanismos específicos de la justicia constitucional existían otros medios procesales útiles para la protección constitucional, como las acciones o recursos contencioso-administrativos, que podían basarse en la violación de normas constitucionales, al igual que las acciones o los mecanismos recursivos del orden civil o penal, los cuales podían propender a la preservación de la integridad de la Constitución. Nos centraremos en los instrumentos propios de la justicia constitucional, esto es, del Derecho Procesal Constitucional.

El sistema de justicia constitucional comprendía formas de control difuso y de control concentrado de la constitucionalidad de las leyes, así como la institución del amparo constitucional. Todo juez de la República era competente para desaplicar leyes referidas al caso sujeto a su conocimiento que considerase contrarias a la Constitución; además, la Corte Suprema de Justicia estaba facultada para declarar la inconstitucionalidad y nulidad de las leyes u otros actos de igual rango violatorios de la Constitución.

En cuanto al amparo constitucional, su consagración constitucional era clara y generosa (art. 49), pero aún no había sido dictada la legislación sobre esta materia prevista en la Constitución, lo cual había impedido, en virtud del criterio sentado por la Corte Suprema de Justicia respecto de la índole programática del correspondiente precepto constitucional (art. 49), que había recibido cierto respaldo doctrinal, la operatividad del instituto procesal, dirigido a la protección de los derechos y garantías constitucionales, incluyendo a los derechos inherentes a la persona no reconocidos expresamente en la Constitución. Sólo el amparo a la libertad personal, o hábeas corpus, era admisible según la jurisprudencia del alto tribunal, dada la existencia de una disposición constitucional transitoria que establecía las reglas de competencia y procedimiento a las que quedaba sometido. Algunos tribunales de instancia habían dado curso a solicitudes de amparo referidas a otros derechos o garantías constitucionales, pero su intención de tornar eficaz la figura del amparo se estrelló con la postura restrictiva de la Corte Suprema de Justicia. 
Conviene apuntar que, pese a la nítida formulación de las modalidades de control concentrado y de control difuso de la constitucionalidad de las leyes en el ordenamiento entonces vigente, el ejercicio práctico de tales instrumentos era bastante limitado, sobre todo en lo que atañe al control difuso de la constitucionalidad.

\section{B. Hitos fundamentales en la evolución jurídico-constitucional desde 1975 hasta el 2005}

a. La promulgación de la Ley Orgánica de la Corte Suprema de Justicia en 1976. La Corte Suprema de Justicia fue creada por la Constitución de 1961, pues la Constitución anterior había establecido un sistema de dualidad en la cúspide del poder judicial, en el cual se preveía una Corte Federal y una Corte de Casación, con sus respectivas leyes orgánicas. La Corte Suprema de Justicia debió funcionar por varios años sin una ley especial, apoyándose en una disposición transitoria de la Constitución y en las leyes orgánicas precedentes.

En 1976 se promulga la Ley Orgánica de la Corte Suprema de Justicia, lo cual implicó algunos cambios en el funcionamiento de la justicia constitucional. En primer término, la Corte en pleno, integrada por todos los Magistrados de la Corte, asumió completamente las atribuciones de control concentrado de constitucionalidad de las leyes $u$ otros actos de igual rango, que hasta entonces compartía con la Sala PolíticoAdministrativa del mismo tribunal. En segundo término, la citada ley reguló los procedimientos para la impugnación de actos ante dicho tribunal, distinguiendo entre la impugnación de actos de efectos particulares y la de actos de efectos generales. Dentro de estos últimos se incluía a las leyes u otras normas del mismo rango, por lo que las respectivas reglas de procedimiento eran aplicables a las acciones o recursos interpuestos para activar el control de constitucionalidad de tales normas. Como aspectos de esta regulación dignos de mención se encuentran la ratificación del carácter amplio $y$, a fin de cuentas, popular de la legitimación para interponer las correspondientes acciones o recursos y la ausencia de un plazo de caducidad.

b. La progresiva utilización del amparo como mecanismo de defensa de derechos y garantías constitucionales. Un capítulo primordial de la evolución de la justicia constitucional en el perio do examinado fue la creciente incursión del amparo en la dinámica judicial, que tuvo su origen en la actuación de los jueces de instancia, con un papel relevante cumplido por los tribunales del interior de la República. En contra del criterio fijado por la Corte Suprema de Justicia, algunos tribunales procedieron a admitir acciones de amparo destinadas a proteger derechos distintos a la libertad física tutelada por el habeas corpus, acudiendo a la analogía para colmar la falta de disposiciones legales relativas al procedimiento y a la competencia judicial. Este avance jurisprudencial terminó repercutiendo en la jurisprudencia de la Corte Suprema de Justicia, que acabó reconociendo la operatividad del amparo aun en ausencia de desarrollo legislativo y fijó criterios basados en la analogía que facilitaban el ejercicio de este medio procesal hasta la promulgación de la ley especial.

Esta sentencia de la Corte Suprema de Justicia, del 20 de octubre de 1983, posee una gran importancia práctica, dogmática y simbólica en nuestra historia constitucio- 
nal. En ella se abandona la tesis, previamente sostenida por la propia Corte, de la existencia de normas meramente programáticas referidas a los derechos y garantías constitucionalmente reconocidos. Además, se sentó un precedente acerca del papel que pueden cumplir los jueces para la defensa de la Constitución, en los casos en los que los otros poderes públicos no hayan estado a la altura de las exigencias constitucionales. De este modo fue salvaguardada la supremacía constitucional y se estableció un criterio garantista que tendría repercusión en los demás órganos jurisdiccionales. A partir de allí el amparo seguiría recorriendo un camino jurisprudencial en el que la Constitución comenzó a hacerse presente en los más diversos órdenes jurisdiccionales y en los rincones más apartados de nuestra geografía, lo cual desembocaría en la promulgación, en 1988, de la Ley Orgánica de Amparo sobre Derechos y Garantías Constitucionales, basada en un proyecto de ley presentado por la vía de la iniciativa popular, que recogía los aportes provenientes de la experiencia jurisprudencial acumulada. Así, pues, el amparo ha sido un modelo concreto de gestación y consolidación institucional, con participación de actores estatales y sociales diversos.

c. Desarrollo del debate académico y público sobre las reformas necesarias para el fortalecimiento de la justicia constitucional. El robustecimiento del amparo como instrumento de tutela judicial reforzada de los derechos constitucionales despertó gran interés en el estudio de la justicia constitucional y de los mecanismos de defensa de la Constitución. Se procuraba insertar el amparo, que había tenido la evolución pretoriana antes esbozada, luego plasmada en la ley, dentro de un contexto sistemático adecuado, en el que estuviese asegurada la protección integral de la Constitución y su cabal interpretación. Bajo el influjo de modelos instaurados en otros ordenamientos y partiendo de nuestros propios antecedentes, desde finales de los años ochenta empezaron a formularse propuestas tendientes a fortalecer el sistema de justicia constitucional.

En un comienzo las reformas planteadas se inscribían en el marco constitucional vigente, el cual preveía la posible creación de una Sala Federal dedicada principalmente al tratamiento de los temas referidos al control de la constitucionalidad de las leyes. Dicha Sala estaría conformada por Magistrados pertenecientes a las Salas ya existentes, con preponderancia de los provenientes de la Sala Político-Administrativa. Se proponía dictar una Ley Orgánica de la Jurisdicción Constitucional que instaurase dentro de la Corte Suprema de Justicia una Sala Federal Constitucional. Esto hubiera supuesto dar un paso hacia la especialización del órgano encargado de ejercer el control concentrado de la constitucionalidad. Las competencias que en el proyecto recibía dicha Sala también ponían de manifiesto la preocupación por garantizar cierta uniformidad en la interpretación constitucional.

Sin embargo, las limitaciones que la misma Constitución imponía para la formulación de reformas de alguna profundidad en el ámbito de la justicia constitucional motivaron posturas más ambiciosas, que comprendían la modificación de la normativa constitucional. Ello quedó reflejado en el Proyecto de Reforma General de la Constitución de 1961 presentado ante el Congreso de la República en 1992 por los integrantes de la Comisión Bicameral de Revisión Constitucional presidida por el ex Presidente Rafael Caldera. Allí se contemplaba la creación de una Sala Constitucional dentro de la Corte Suprema de 
Justicia, a la cual se enmendaba el ejercicio de las atribuciones de control de la constitucionalidad hasta entonces reservadas a la Corte en pleno.

Ninguna de estas propuestas de reforma prosperó, como tampoco otras posteriores que volvían a planteamientos de menor alcance sometidos a la normativa constitucional vigente o que presuponían una puntual enmienda de la Constitución. Con base en estas iniciativas y en las reflexiones que les brindaron soporte, las modificaciones se introdujeron mediante la aprobación de la Constitución de 1999, a la que seguidamente nos referiremos.

d. La justicia constitucional en la Constitución de $1999 .{ }^{131}$ La Constitución de la República Bolivariana de Venezuela, sancionada popularmente en 1999, introdujo sustanciales mejoras en la regulación de la justicia constitucional. Para apreciar su significación conviene recordar que, de acuerdo con el Texto Constitucional anterior, las competencias relacionadas con el control concentrado de la constitucionalidad de las leyes recaían sobre la Corte Suprema de Justicia en Pleno (Sala Plena), la cual estaba conformada por los Magistrados de las Salas de Casación Penal, de Casación Civil y Político Administrativa de dicha Corte. No se trataba, pues, de un órgano especializado en la materia constitucional, ni siquiera de un órgano judicial de funcionamiento permanente, sino de una Sala que sesionaba para ejercer las escasas atribuciones conferidas por el ordenamiento. El trabajo de la Corte Suprema de Justicia se desarrollaba normalmente en el ámbito de cada una de sus Salas particulares, compuestas por cinco Magistrados, ya de por sí bastante sobrecargados de causas, mientras que las reuniones en Sala Plena se apartaban de lo habitual y a menudo se traducían en retardos excesivos en la resolución de los casos. Adicionalmente, la ausencia de una sensibilidad hacia los temas constitucionales quedaba evidenciada en los contenidos sustantivos de la jurisprudencia, reacia a captar y a desplegar toda la fuerza normativa de la Constitución, en especial de su parte dogmática.

Por otra parte, la amplitud y diversidad de los mecanismos que estaban a disposición de los jueces ordinarios para la protección específica de la Constitución, como el amparo y el control difuso de la constitucionalidad, condujo a pensar en la conveniencia de introducir mecanismos que permitieran asegurar una mayor certeza jurídica frente al ejercicio del control difuso de la constitucionalidad, el cual podía ser activado por cualquier juez de la República, al estar facultado para desaplicar al caso particular sometido a su conocimiento las leyes que considerase inconstitucionales, sin que existieran instrumentos procesales orientados a provocar un pronunciamiento definitivo y con alcance general sobre la inconstitucionalidad de la ley en cada uno de estos supuestos de inaplicación legislativa. En materia de amparo también se había observado que podían presentarse interpretaciones judiciales disímiles respecto de los aspectos

131 Vid. Casal H., Jesús M., Constitución y Justicia Constitucional, Caracas, UCAB, 2004. Respecto del actual sistema de justicia constitucional pueden consultarse también, entre otros, los trabajos de BREWER-CARíAs, Allan, El sistema de justicia constitucional en la Constitución de 1999, Caracas, EJV, 2000; HARO, José Vicente, "La justicia constitucional en Venezuela y la Constitución de 1999", Revista de Derecho Constitucional, 1, 1999, pp. 151 y ss.; CANOva, Antonio, "La Futura justicia constitucional en Venezuela", Revista de Derecho Constitucional, 2, 2000, pp. 104 y ss. 
procesales de la institución o del propio alcance de los derechos tutelados, ya que el amparo se rige por el principio de la doble instancia, la cual frecuentemente se agotaba ante los Tribunales Superiores de los variados órdenes jurisdiccionales o, en determinados supuestos, ante las Salas de la Corte Suprema de Justicia, según la naturaleza del asunto, suscitándose a veces diferencias interpretativas entre ellas.

Las consideraciones anteriores llevaron a la consolidación de una opinión favorable a la creación de una alta instancia jurisdiccional especializada en la materia constitucional, que asumiera las atribuciones de control concentrado de la constitucionalidad de las leyes y otras propias de la jurisdicción constitucional, como los conflictos constitucionales, y que velara por el cabal ejercicio de instrumentos como el amparo y el control difuso de la constitucionalidad.

Se debatió sobre la conveniencia de instaurar una Sala o un Tribunal Constitucional, y prevaleció la tesis de la inclusión de una Sala Constitucional dentro del Máximo Tribunal. Para algunos esta alternativa ofrecía la ventaja de minimizar los conflictos que pudieran suscitarse entre la jurisdicción ordinaria y la constitucional, en particular, entre un Tribunal Constitucional y la Corte o Tribunal Supremo de Justicia, que habían alcanzado en ocasiones singular intensidad en países europeos y latinoamericanos. Otros estimaron que la Sala Constitucional podía ser un paso intermedio o gradual, un estadio previo a la creación de un Tribunal Constitucional, el cual permitiría acumular una experiencia que seguramente habría de desembocar en la adopción de esta última figura.

Ello aunado al efecto vinculante reconocido a la jurisprudencia constitucional de dicha Sala y a su facultad de revisión de sentencias de amparo o de control difuso, y a la introducción en nuestro ordenamiento de novedosos medios procesales para la protección de la Constitución, como la acción de inconstitucionalidad por omisión legislativa, el control previo de la constitucionalidad de los tratados internacionales suscritos por la República y el control automático o de oficio de los decretos de estados de excepción, abona la conclusión de que la normativa de la Carta Magna de 1999 apunta hacia el fortalecimiento y racionalización de la justicia constitucional.

Se mantuvieron los rasgos fundamentales del sistema venezolano de justicia constitucional, que se sigue distinguiendo por su carácter mixto o integral, es decir, por la convivencia entre los principales instrumentos del control concentrado de la constitucionalidad y el control difuso, al igual que por la preponderancia del amparo como medio de protección constitucional. Pero se especializó la máxima instancia de la justicia constitucional y se le confirieron nuevas atribuciones, algunas de ellas dirigidas a ordenar o racionalizar el funcionamiento de mecanismos tradicionales de ese sistema.

La incorporación de este nuevo actor, la Sala Constitucional del Tribunal Supremo de Justicia, podía indiscutiblemente ocasionar algunas variaciones en la dinámica general del sistema de justicia constitucional, mas su función directiva o rectora dentro del mismo debía conducir al aprovechamiento o estímulo de las potencialidades de cada uno de sus elementos, con base en la pluralidad típica del modelo difuso de control, no a la absorción competencial que, como de inmediato veremos, ha caracterizado la jurisprudencia de la Sala Constitucional. 
e. La aplicación de la nueva regulación constitucional y la Ley Orgánica del Tribunal Supremo de Justicia. ${ }^{132}$ La Constitución perfila a la Sala Constitucional como una instancia de igual rango que el de las demás Salas del Tribunal Supremo de Justicia, pero dotada de una posición preferente en la interpretación constitucional, por cuanto su jurisprudencia goza, en esta esfera y dentro de ciertos límites, de un efecto vinculante general o erga omnes. De ahí que la Sala Constitucional sea, en esta materia, un órgano primus inter pares.

Desde un primer momento se planteó, sin embargo, el interrogante de si la Sala Constitucional podía anular o revisar sentencias emanadas de otras Salas del Tribunal Supremo de Justicia con base en el numeral 10 del artículo 336 de la Constitución. A lgunos estimamos que la respuesta debía ser negativa, pues la mencionada primacía interpretativa de la Sala Constitucional no la convierte en órgano de revisión de las sentencias proferidas por las Salas hermanas del M áximo Tribunal, del cual forma parte. El artículo 335 de la Constitución, frecuentemente invocado para justificar tal potestad revisora, ciertamente prevé, dentro de determinados límites, el especial efecto vinculante de la jurisprudencia de la Sala Constitucional, pero ello no autoriza a esta Sala a imponer su criterio constitucional en cualquier caso y por cualquier vía. Al contrario, sus interpretaciones vinculantes deben sentarse en uso de las atribuciones procesales efectivamente otorgadas por la Constitución, o por la ley conforme a la Constitución, la cual no la erige en órgano de revisión general de los pronunciamientos de las demás en materia constitucional. El artículo 335 podía, a lo sumo, conferir fundamento a un mecanismo procesal, que debía ser configurado por la ley, por el cual la Sala Constitucional revisara sentencias de las otras Salas contrarias a la doctrina vinculante previamente sentada por dicha Sala.

Sin embargo, la Sala Constitucional, con apoyo en una Exposición de M otivos de la Constitución de validez más que dudosa y en el afán de extender su ámbito de competencias, asumió desde el principio de su jurisprudencia una facultad para revisar, de oficio o a instancia de parte, cualquier decisión de las otras Salas que ella estimase gravemente lesiva de la Constitución o contraria a las interpretaciones que ella misma hubiera establecido. Ello abrió la brecha de la tendencia a la auto-atribución de competencias por parte de la Sala Constitucional, que simultáneamente se estaba produciendo en la materia del amparo constitucional, pues la Sala mencionada se reservó todas las competencias que tenía el máximo tribunal para conocer de acciones de amparo autónomas tanto en única instancia como en vía de apelación o consulta.

La tendencia señalada se ha trasladado a varios ámbitos: la obligación de los jueces de remitir a dicha Sala, para su revisión, toda sentencia en la que ejerzan el control difuso de la constitucionalidad; la reducción de la facultad de los jueces de desaplicar leyes incompatibles con la Constitución a los casos de contradicción literal; el reconocimiento de una facultad de la Sala Constitucional de avocarse al conocimiento de causas

132 Respecto de esta evolución vid. CASAL H., Jesús M., "Los actuales desafíos de la justicia constitucional en Venezuela", Estado de Derecho, Administración de Justicia y Derechos Humanos, XXX Jornadas J.M. Domínguez Escovar", Barquisimeto, IEJEL, 2005, pp. 287-333. 
pendientes de tramitación o decisión ante cualquier otro tribunal, en materia constitucional; el monopolio de esa Sala para resolver acciones interpuestas en defensa de intereses difusos o colectivos; la creación de un recurso directo de interpretación de la Constitución; el sobredimensionamiento del efecto vinculante de la jurisprudencia constitucional, y los poderes de dicha Sala para colmar omisiones inconstitucionales de todos los poderes públicos. Esta orientación ha sido en buena medida confirmada por la Ley Orgánica del Tribunal Supremo de Justicia, promulgada en el 2004.

Todo lo anterior ha conducido a un desmesurado incremento de las atribuciones de la Sala Constitucional, lo cual ha ido en detrimento de las facultades de los jueces ordinarios para la interpretación y defensa de la Constitución y ha mitigado el carácter mixto o integral de nuestro sistema de justicia constitucional.

\section{ASPECTOS SINGULARES DE LA EVOLUCIÓN POLIITICO-CONSTTTUCIONAL: LA REFORMA CONSTITUCIONAL INCONSTITUCIONAL DE 2007}

Una vez reelecto el Presidente Chávez en diciembre del año 2006 para un nuevo y último período constitucional 2007-2012 y que tomó posesión del cargo en febrero de 2007, dictó un decreto creando un "Consejo Presidencial de Reforma Constitucional", caracterizada por dos elementos: primero, que sus trabajos se harían en la más "estricta confidencialidad"; 133 y segundo, que los miembros que la integraban eran fundamentalmente diputados oficialistas y miembros del Poder Ejecutivo y de los otros poderes públicos "independientes" como era el caso del Defensor del Pueblo (Germán Mundaraín) y el Fiscal General de la República (Isaías Rodríguez) y la propia Presidenta del Tribunal Supremo de Justicia y de su Sala Constitucional (Luisa Estella M orales), quien fue designada en el decreto como la Secretaria Ejecutiva del Consejo Presidencial. ${ }^{134}$ El trabajo de ese Consejo culminó en los documentos que le fueron presentados al Presidente de la República y que sirvieron de base para que éste formulara el proyecto de reforma constitucional que presentó para su aprobación ante la A samblea Nacional el 15 de agosto de 2007. La reforma constitucional fue aprobada por la Asamblea Nacional el 2 de noviembre de ese año y ese mismo día el Consejo Nacional Electoral dispuso que fuera sometida al referendo el cual se convocó para el día 2 de diciembre de 2007. Es notorio observar, la reforma constitucional aprobada por la Asamblea Nacional fue posteriormente impugnada ante la Sala Constitucional aun antes de la celebración del referendo y en esa oportunidad algunos de los accionantes recusaron a la magistrada y Presidenta de esa Sala, Luisa Estella Morales, no sólo por tener interés directo al haber integrado el citado Consejo Presidencial en su condición de miembro y Secretaria Ejecutiva, sino por haber adelantado opinión en la

133 Artículo 2 del Decreto № 5.138 mediante el cual se crea, con carácter temporal, el Consejo Presidencial para la Reforma de la Constitución de la República Bolivariana de Venezuela, publicado en la Gaceta Oficial № 38.607 del 18 de enero de 2007.

${ }^{134}$ A rtículo 1 del Decreto № 5.138 mediante el cual se crea, el Consejo Presidencial para la Reforma de la Constitución de la República Bolivariana de Venezuela. 
prensa. Dicha recusación fue declarada sin lugar por el Vicepresidente de esa Sala, el magistrado Jesús Eduardo Cabrera. ${ }^{135}$

\section{A. Los vicios de procedimiento}

La "Reforma Constitucional" sancionada por la A samblea Nacional en el año 2007, aparte de no ser una "Reforma" en cuanto a los límites de contenido dispuestos en la propia Constitución en su artículo 342, constituía una vía de hecho puesto que ni siquiera fue seguido el procedimiento mismo que era necesario para que se produjera tal "Reforma Constitucional".

En efecto, en primer lugar, la "Reforma Constitucional" partió de una iniciativa del Presidente de la República que incluía 33 Artículos, en cuya Exposición de Motivos aparece un subtítulo que denomina la iniciativa como "Proyecto de la Reforma Constitucional" (ver,http:/www.abn.info.ve_reforma_constitucional.ph). Esa iniciativa fue entregada a la A samblea Nacional para su discusión, el día 15 de agosto de 2007. De acuerdo con el artículo 343 de la Constitución, la iniciativa de Reforma Constitucional debe ser tramitada por la Asamblea Nacional en tres discusiones con ciertas modalidades y oportunidades expresamente pautadas. ${ }^{136}$

El Proyecto de Reforma fue presentado a la A samblea Nacional el día 15 de agosto de 2007, ello quiere decir que fue presentado el último día del primer periodo de sesiones ordinarias. Entonces, era sencillamente imposible que la iniciativa de Reforma Constitucional presentada por el Presidente de la República, pudiera ser objeto de la primera discusión dentro del periodo en el cual fue presentado, ya que ese periodo de sesiones estaba venciendo el mismo día en que se introdujo el Proyecto.

A dicionalmente, la "Reforma Constitucional" partió de una iniciativa Presidencial que incluía 33 Artículos. Sin embargo, entre los días 12 de octubre (día feriado nacional) y 15 de octubre, la A samblea Nacional decidió incorporar a esa iniciativa 24 Artículos más, junto con once (11) Disposiciones Transitorias, tampoco incluidas en la iniciativa Presidencial. De esa adición de artículos que no estaban contemplados en la

135 Decisión del Vicepresidente de la Sala Constitucional del TSJ de fecha 22-11-07. Las decisiones del TSJ pueden ser consultadas en el siguiente sitio o portal digital oficial: www.tsj.gov.ve

136 Las normas pertinentes de la Constitución de 1999 disponen:

Artículo 343: La iniciativa de Reforma Constitucional será tramitada por la Asamblea Nacional en la forma siguiente:

1. El proyecto de Reforma Constitucional tendrá una primera discusión en el periodo de sesiones correspondiente a la presentación del mismo.

2. Una segunda discusión por Titulo o Capítulo, según fuese el caso.

3. Una tercera y ultima discusión artículo por artículo (... "). (resaltados y cursivas añadidos).

Artículo 219: El primer período de las sesiones ordinarias de la Asamblea Nacional comenzará, sin convocatoria previa, el cinco de enero de cada año o el día posterior más inmediato posible y durará hasta el quince de agosto".

El plazo del primer período de las sesiones ordinarias de la A samblea Nacional establecido en la citada norma, no es susceptible de ser prorrogado. (Resaltados y cursivas añadidos). 
iniciativa presidencial, resultaron añadidos por tanto: 36 nuevos Artículos y 14 nuevas Disposiciones Transitorias. Esos A rtículos nuevos ni siquiera fueron objeto de las tres (3) discusiones que exige el artículo 343 de la Constitución vigente.

A simismo, distintas normas contenidas en la reforma aprobada por la Asamblea Nacional y sometida a referendo, violaba materialmente los límites del poder de reforma, representados en las cláusulas intangibles de la estructura y los principios de la Constitución de 1999. Entre estas violaciones, por razones de espacio, resaltaremos las siguientes: ${ }^{137}$

B. La violación del Principio Fundamental de la preeminencia de los derechos humanos

El artículo 342 de la Constitución, establece claramente dos límites a la Reforma Constitucional: 1. la estructura del texto Constitucional; y 2. los Principios del Texto Constitucional. ${ }^{138}$ La "Reforma Constitucional" aprobada por la A samblea Nacional violaba "la preeminencia de los derechos humanos" como Principio Fundamental del Texto Constitucional conforme a su artículo 2 (Título I: "PRINCIPIOS FUNDAMENTALES").

En tal virtud, una normativa que configura una disminución o regresión en materia de derechos humanos como la contenida en la Reforma Constitucional propuesta en el año 2007, no sólo no puede ser el resultado del procedimiento para la aprobación de "reformas constitucionales" contemplado en los A rtículos 342 al 346 de la Constitución, sino que tampoco puede llevarse a cabo mediante una Asamblea Nacional Constituyente.

En este sentido es importante recordar que entre los límites precisamente del poder constituyente ejercido a través de la convocatoria a una Asamblea Nacional Constituyente realizada en 1999 tras el referendo celebrado el 15 de abril de 1999, se estableció la siguiente Base Comicial:

Octavo: Una vez instalada la Asamblea Nacional Constituyente, deberá dictar sus propios estatutos de funcionamiento, teniendo como límites los valores y principios de nuestra historia republicana, así como el cumplimiento de los tratados internacionales, acuerdos y compromisos válidamente suscritos por la República, el carácter progresivo de los derechos fundamentales del hombre y las garantías democráticas dentro del más absoluto respeto de los compromisos asumidos. (Resaltados añadidos).

137 Para un estudio más completo de la reforma constitucional, su contenido y sus vicios, ver A YALA CoRAO, Carlos, "De la Constituyente de 1999 a la Reforma de 2007", en publicación en prensa en la UNAM sobre Los procesos constituyentes.

138 El texto de la norma constitucional es el siguiente:

Artículo 342. La Reforma Constitucional tiene por objeto una revisión parcial de esta Constitución y la sustitución de una o varias de sus normas que no modifiquen la estructura y principios fundamentales del texto Constitucional. (Resaltados y cursivas añadidos). 
Igualmente, el principio de progresividad quedó consagrado en el artículo 19 de la Constitución de 1999. ${ }^{139}$ El propio Preámbulo de la Constitución establece que ésta se dictó en "ejercicio de su poder originario representado por la A samblea Nacional Constituyente mediante el voto libre y en referendo democrático"; y como propósito fundamental de la nueva Carta Fundamental dispuso "la garantía universal e indivisible de los derechos humanos".

Ello significa, como se dijo, que los derechos consagrados por la Constitución no pueden ser posteriormente desconocidos ni disminuidos, ya que su naturaleza de ser "inherentes a la persona" una vez reconocida no puede ser revertida (art. 22, Constitución). A sí la jurisprudencia de la Corte Interamericana ha definido a la progresividad y la irreversibilidad como dos elementos consustanciales de los derechos humanos. ${ }^{140}$

No obstante ello, la Reforma Constitucional desconocía y revertía de manera claramente regresiva, derechos constitucionales consagrados y reconocidos en la Constitución de 1999.

a. La regulación constitucional de los estados de excepción. En primer lugar, resultaban graves los vicios contenidos en las modificaciones que contenía la Reforma Constitucional aprobada en lo concerniente a la regulación constitucional de los estados de excepción, pues se reducían las cautelas y controles previstos en la Constitución de 1999 y se excluían derechos no susceptibles de restricción con motivo de un estado de excepción en la Constitución de 1999 en su artículo 337. En tal sentido, la Reforma pretendía restaurar la figura de la suspensión (en lugar de la restricción) de garantías, de nefastas consecuencias en la experiencia constitucional venezolana ya que no permitió explicar adecuadamente el alcance de los estados de excepción. De allí que la Constitución de 1999 en su momento haya optado por la expresión y el concepto de la "restricción" de garantías, conforme a la cual, ni siquiera en circunstancias extraordinarias podían suspenderse las garantías de los derechos, como lo ha interpretado de manera auténtica la Corte Interamericana de Derechos Humanos, particularmente a través de sus Opiniones Consultivas números 8 y $9 .{ }^{141}$ Adicionalmente, se planteó la supresión de los límites temporales establecidos en el artículo 338 de la Constitución, lo que nos colocaba ante el riesgo de estados de excepción prolongados o incluso ilimitados, como los excesos ya conocidos; y se eliminaba la prohibición de restringir "los demás derechos humanos intangibles". Se eliminaba, además, la facultad de la A sam-

139 El texto de la norma constitucional es el siguiente:

Artículo 19. El Estado garantizará a toda persona, conforme al principio de progresividad y sin discriminación alguna, el goce y ejercicio irrenunciable, indivisible e interdependiente de los derechos humanos. Su respeto y garantía son obligatorios para los órganos del Poder Público, de conformidad con esta Constitución, con los tratados sobre derechos humanos suscritos y ratificados por la República y con las leyes que los desarrollen. (Resaltados añadidos).

140 Corte IDH. Restricciones a la pena de muerte -arts. 4.2 y 4.4. Convención A mericana sobre Derechos Humanos-, Opinión Consultiva OC-3/83 del 8 de septiembre de 1983, Serie A, № 3, párrs. 56 y 57.

141 Ver, Corte IDH. El hábeas corpus bajo suspensión de garantías -arts. 27.2, 25.1 y 7.6 Convención Americana sobre Derechos Humanos-, Opinión Consultiva OC-8/87 del 30 de enero de 1987, Serie A, № 8; y Corte IDH. Garantías judiciales en estados de emergencia-arts. 27.2, 25 y 8 Convención A mericana sobre Derechos Humanos-, Opinión Consultiva OC-9/87 del 6 de octubre de 1987, Serie A, № 9. 
blea Nacional o de la Comisión Delegada de intervenir para revocar el decreto que declara el estado de excepción, al cesar las causas que lo motivaron. Desaparecía también la alusión al deber de remitir el decreto respectivo a la Sala Constitucional del Tribunal Supremo de Justicia para el control previo de su constitucionalidad. Especial gravedad revestía la propuesta de sustraer la libertad de información y elementos esenciales del derecho al debido proceso de la enunciación de las garantías no susceptibles de restricción o suspensión (artículo 337).

Igualmente resultaba violatorio a los derechos humanos y a su progresividad, la eliminación de la norma contenida en la Constitución de 1999 que hacía la reforma impugnada en su artículo 339 al Pacto Internacional de Derechos Civiles y Políticos y a la Convención Americana sobre Derechos Humanos, en lo que atañe a las exigencias, principios y garantías que establecen al regular los estados de excepción.

b. La restricción ideológica del derecho político a la participación. En segundo lugar, la propuesta de Reforma Constitucional contemplaba la modificación del artículo 70 de la Constitución para reducir los medios de participación y protagonismo del pueblo en ejercicio de su soberanía para "la construcción del socialismo". Conforme a lo expresado por el Presidente de la República en su discurso de presentación del proyecto de Reforma Constitucional en la A samblea Nacional el 15-8-07, "sólo en socialismo será posible la verdadera democracia". No obstante, lo correcto es sostener que sólo en una democracia es posible un socialismo democrático. La participación democrática de los ciudadanos y ciudadanas en el ejercicio de su soberanía es un derecho propio reconocido en la Constitución de 1999 y en instrumentos internacionales como la Convención A mericana sobre Derechos Humanos (art. 23), que no está ni puede estar restringido o limitado a la "construcción del socialismo" ni a ningún otro modelo determinado, sino a la construcción de la democracia, pura y sencillamente. En todo caso, el socialismo democrático es sólo una opción o un modelo político, pero en ningún caso puede ser la única para todos los ciudadanos y ciudadanas. Por ello no se pueden restringir los medios de participación ciudadana únicamente con el objetivo de "construcción del socialismo", ya que son mecanismos que permiten la realización del derecho a la participación de todos los ciudadanos y ciudadanas en los asuntos públicos, en ejercicio de la soberanía popular.

c. La restricción de los mecanismos de democracia directa. En tercer lugar, la Reforma Constitucional desmejoraba, agravaba y hacía más difícil el ejercicio del derecho político de los ciudadanos y ciudadanas a través de mecanismos de democracia directa, como son las iniciativas y los referendos.

M ediante el cuadro que exponemos a continuación se evidencia con toda claridad esta desmejora de los derechos de participación política directa a que hacemos referencia:

1. REFERENDOS CONSULTIVOS (ART. 71):

- INICIATIVA POPULAR:

$1999->2007$

$10 \%->20 \%$ 
2. REFERENDOS REVOCATORIOS (ART. 72) :

- INICIATIVA POPULAR:

- QUÓRUM :

$20 \%->30 \%$

$25 \%->40 \%$

3. REFERENDOS A PROBATORIOS DE TRATADOS (ART. 73):

- INICIATIVA POPULAR:

- QUÓRUM :

$15 \%->30 \%$

$->\mathbf{3 0} \%$

4. REFERENDOS A PROBATORIOS DE LEYES (ART. 73):

- QUÓRUM :

$25 \%->30 \%$

5. REFERENDOS A PROBATORIOS DE LEYES (ART. 74):

- INICIATIVA POPULAR:

$10 \%->30 \%$

6. REFERENDOS A PRO BATORIOS DE DECRETOS-LEYES (ART. 74):

- INICIATIVA POPULAR:

$5 \%->30 \%$

7. ENMIENDAS A LA CONSTITUCIÓN (ART. 341):

- INICIATTVA POPULAR:

$15 \%->20 \%$

8. REFORMAS A LA CONSTITUCIÓN (ART. 342):

- INICIATIVA POPULAR:

$15 \%->25 \%$

9. CONVOCATORIA A ASAMBLEA NACIONAL CONSTTTUYENTE (ART. 348):

- INICIATIVA POPULAR:

$15 \%->30 \%$

d. La estatización de la sociedad en un Poder Popular "asambleario" no electo por voto secreto, libre e individual. En cuarto lugar, la Reforma Constitucional incorporaba un "Poder Popular" dentro de la distribución territorial del Poder Público del Estado, mediante el cual se proponía que el pueblo ejerza la soberanía popular directamente, pero el cual "no nace del sufragio ni de elección alguna, sino que nace de la condición de grupos humanos organizados como base de la población" (art. 136) (resaltado añadido). En ese sentido, conforme a las normas propuestas en la reforma, el Poder Popular se expresa "constituyendo las comunidades, las comunas y el autogobierno de las ciudades, a través de los consejos comunales, los consejos obreros, los consejos campesinos, los consejos estudiantiles y otros entes que señale la ley" (art. 136). A fin de llevar a cabo estos mecanismos del Poder Popular, la propuesta de Reforma Constitucional establecía como mecanismo de nombramiento de sus autoridades que la "Comunidad organizada tendrá como máxima autoridad la Asamblea de ciudadanos quien en tal virtud designa y revoca a los órganos del Poder Comunal en las comunidades, Comunas y otros entes político-territoriales" y el "Consejo Comunal" se constituye en "el órgano ejecutor de las decisiones de las asambleas" (subrayado añadido) (art. 184). Si bien valoramos positivamente que se reconociera el Poder Popular y la participación ciudadana en el poder; denunciamos que se trataba de una propuesta que modificaba el principio democrático de la soberanía popular y su ejercicio a través 
de la elección popular de las autoridades como Principio Fundamental de la Constitución de 1999. La democracia participativa supone la integración de elementos de la democracia directa y la representativa, pero nunca puede implicar la renuncia a la segunda, es decir, al sufragio. El proyecto presentado establecía sólo mecanismos asamblearios (incluso en la elección de los miembros al Consejo Comunal) limitando así el ejercicio democrático del poder. Por lo cual, resultaba afectado el Principio Fundamental de la Constitución del sufragio como ejercicio de la soberanía popular, es garantizado como un derecho mediante votaciones libres, universales, directas y secretas (art. 64). Ese sufragio libre y secreto como garantía para el ejercicio del derecho fundamental, constitucional y humano al ejercicio de la soberanía popular como Principio Fundamental de la Constitución era vulnerado con la propuesta del Poder Popular antes analizada.

e. La eliminación de los derechos a la "libertad" de trabajo y a la libertad económica. En quinto lugar, el derecho a la "libertad" de trabajo existente en la Constitución de 1999 (artículo 87), era modificado por un enunciado restrictivo, ya que mientras el enunciado actual establece un derecho amplio que puede ser regulado mediante ley, la propuesta de Reforma Constitucional inicialmente consideraba al trabajo como un derecho que sólo podía ser ejercido dentro del marco de lo que el Estado permitiera mediante ley (artículo 87). Con ello, el trabajo dejaría de ser un "derecho" humano inherente que puede ser desarrollado por la ley, para ser una "potestad" de regulación del Estado fuera de la cual no habría derecho alguno.

Igualmente la Reforma propuesta eliminaba el derecho de todas las personas a dedicarse a la actividad económica de su preferencia con las limitaciones que establezcan las leyes, así como el deber del Estado de promover la iniciativa privada (art. 112). La eliminación de este derecho conlleva a un sistema donde las actividades económicas sólo se puedan llevar a cabo por definición del Estado de "un Modelo Económico Productivo, intermedio, diversificado e independiente" para "la construcción colectiva y cooperativa de una economía socialista" (art. 112). Esta nueva regulación desconocía ese derecho de las personas contenido en la Constitución de 1999 y lo eliminaba, sustituyéndolo por simplemente por unas potestades reguladoras del Estado para la construcción de un modelo económico determinado.

f. Las restricciones al derecho de propiedad. En relación con la modificación anterior, en sexto lugar, la Reforma Constitucional modificaba la consagración del contenido de la norma relativa al derecho de propiedad (art. 115), para reconocer y garantizar las diferentes "formas" de propiedad: pública, social indirecta y directa, colectiva, mixta y privada. En relación con la propiedad privada, la misma se reconocía únicamente sobre "bienes de uso y consumo y medios de producción legítimamente adquiridos" (art. 115).

En primer lugar es importante resaltar que el problema de Venezuela continúa siendo la pobreza y la desigual distribución de la riqueza pública y privada. El objetivo social y económico de las políticas públicas debe ser garantizar un mayor acceso a la propiedad, particularmente a la vivienda digna, a la tierra, a un salario justo y a medios de trabajo, a las personas más necesitadas. 
Por lo cual, si bien valoramos la propuesta de incorporar distintas formas de propiedad pública y social en la Constitución, la formulación propuesta sobre la propiedad dejaba de reconocer y garantizarla como un "derecho", para simplemente hacerlo respecto a las "formas" de propiedad.

Por otro lado, si bien los otros tipos de propiedad no contenían restricciones respecto a los bienes apropiables u objeto de propiedad, la privada sólo se reconocía, como vimos, sobre bienes de "uso y consumo" y "medios de producción legítimamente adquiridos". En primer lugar, estas categorías no son jurídicamente determinadas, son más económicas y hasta ideológicas, por lo cual se prestan a una posterior determinación incluso por ley que deje por fuera arbitrariamente a determinadas categorías de bienes. En segundo lugar, el requisito de que los medios de producción deben ser "legítimamente adquiridos", plantea serias interrogantes como ¿Qué se entiende por tales? ¿Quién determina la legitimidad de su adquisición? Se trata por tanto de la imposición de unas exclusiones a la propiedad y su sometimiento a condicionamientos irrazonables, que restringe arbitrariamente el derecho a la propiedad de las personas. La propiedad es un derecho humano de todas las personas, reconocido en la Convención A mericana sobre Derechos Humanos (art. 21) sobre sus bienes, lo cual no obsta, para que en virtud de su función social la ley deba razonablemente subordinar su uso y goce al interés social. Por ello no creemos en la propiedad pública, ni en la social, ni en la cooperativa ni en la privada como derechos absolutos o ilimitados.

En definitiva, es evidente que la Reforma Constitucional de 2007 constituía una clara regresión en los logros alcanzados en materia de derechos humanos en la Constitución de 1999.

\section{La sustitución del Estado social y democrático de Derecho y de Justicia por el "Estado Socialista"}

La Constitución vigente (1999) establece que la República Bolivariana de Venezuela es un "Estado democrático y social, de Derecho y de Justicia", en el cual se propugnan como "valores superiores de su ordenamiento jurídico" y de "su actuación", "la vida, la libertad, la justicia, la igualdad, la solidaridad, la democracia, la responsabilidad social y, en general, la preeminencia de los derechos humanos, la ética y el pluralismo político (... )". (Resaltados nuestros).

La Reforma Constitucional planteaba la sustitución del “Estado democrático y social, de Derecho y de Justicia" previsto en la Constitución de 1999, por un nuevo modelo de "Estado Socialista" como núcleo básico e indivisible de la nueva estructura de la organización territorial nacional (art.16).

El modelo de "Estado Socialista" incorporado en la Reforma Constitucional iba unido a la propuesta de incorporación de la "Democracia Socialista". En este sentido, se proponía la modificación del artículo 158 de la Constitución, para establecer que el Estado promoverá la participación protagónica del pueblo "para la construcción de una Democracia Socialista". Conforme a lo expresado por el Presidente de la Repú- 
blica en su discurso de presentación del proyecto de Reforma Constitucional en la A samblea Nacional el 15-8-07, "sólo en socialismo será posible la verdadera democracia". No obstante, lo correcto desde el punto de vista democrático es sostener, que sólo en una democracia es posible un socialismo democrático.

\section{La sustitución del Estado Federal Descentralizado por una centralización nacional}

La forma de Estado perseguido por la "Nueva Geometría del Poder" que se proponía en la Reforma Constitucional de 2007, suponía una modificación del esquema de reparto de competencias y atribuciones del Presidente de la República del "Estado Federal Descentralizado" consagrado en la Constitución de 1999, referido a las siguientes materias, que por razones espacio no podremos desarrollar en este trabajo: ${ }^{142}$

a. La "Nueva Geometría del Poder";

b. La creación de Provincias Federales, Ciudades Federales y Distritos Funcionales y el nombramiento de sus autoridades por el Presidente de la República;

c. La ordenación y gestión centralizada del Estado;

d. La organización político territorial del Estado Socialista;

e. La re-centralización de competencias estadales y la eliminación de las competencias residuales de los estados;

f. La eliminación de la cláusula de descentralización; y

g. El régimen centralizado de Caracas como ciudad Capital y la re-creación del Distrito Federal.

\section{E. La alteración del sistema presidencial y del principio constitucional de la alternatividad}

La Reforma Constitucional hacía mucho más poderoso al Presidente de la República, al aumentar su período y permitir su reelección ilimitada, y al aumentar sus facultades y competencias.

a. El aumento del perío do del Presidente. La propuesta consistió en aumentar el período constitucional del Presidente de 6 años a 7 años, con el argumento de contar con los años suficientes para llevar a cabo el programa propuesto (RC, art. 230). Con ello el Presidente venezolano pasaba a tener el período más largo de todos los presidentes en Latinoamérica y el más largo de los períodos de nuestra historia constitucional, sólo igual al establecido por las Constituciones de la dictadura de Juan Vicente Gómez.

142 Ver, entre otros, Ayala Corao, Carlos. “De la Constituyente de 1999 a la Reforma Constitucional de 2007", en libro sobre Los Procesos Constituyentes en América Latina, UNAM, M éxico. 2008 (en prensa); Brewer-Carías, Allan. La Reforma Constitucional de 2007 (Comentarios al Proyecto Inconstitucionalmente sancionado por la A samblea Nacional el 2 de noviembre de 2007). Colección textos legislativos № 43, Editorial Jurídica Venezolana, Caracas, 2007. 
b. La reelección ilimitada del Presidente. La propuesta consistía en eliminar la limitación contenida en la Constitución de 1999 para reelegir al Presidente "por una sola vez", para que así éste pueda ser reelecto ilimitadamente (RC, art. 230). El argumento para sustentar esta propuesta ha sido que la limitación a la reelección presidencial es un invento del imperialismo norteamericano; que para la continuación y consolidación del actual proceso revolucionario es necesario mantener al Presidente Chávez como su líder; y que hay que dejar que sea el pueblo quien decida si quiere o no reelegir ilimitadamente a los presidentes. ${ }^{143}$

Ello sustenta la conveniencia de que la Constitución garantice la alternabilidad del gobierno, estableciendo límites a la reelección del Presidente. En este sentido, la Constitución de 1999 consagra entre sus Principios Fundamentales que el gobierno de la República Bolivariana de Venezuela es y será siempre "alternativo".

c. El aumento irrazonable de las facultades y competencias del Presidente. La Reforma Constitucional proponía un aumento desmesurado las facultades y competencias que tiene asignadas el Presidente de la República en la Constitución de 1999. Las principales facultades y competencias adicionales que se asignaban expresa y directamente al Presidente de la República en la Reforma Constitucional, eran las siguientes:

${ }^{143}$ Hasta la fecha en ningún país latinoamericano las Constituciones autorizan la reelección ilimitada del Presidente. En este sentido, en Venezuela, con excepción de las constituciones de 1957 (que duró apenas meses), y los dictadores Juan Vicente Gómez y Pérez Jiménez que no contenían límites expresos a la reelección, las demás constituciones hasta la de 1999 (a excepción de la de 1811) han autorizado la reelección de los presidentes ya sea de manera inmediata o después de transcurrir uno o más períodos. La idea detrás de limitar la reelección de los presidentes en Latinoamérica es impedir que los mandatarios se perpetúen en el poder, aun cuando puedan tener apoyo popular. Ello ha llevado a acoger constitucionalmente el principio del gobierno democrático "alternativo", que va desde la prohibición absoluta de reelección en M éxico y la mayoría de los países centroamericanos como una cláusula no modificable ("pétrea") y la prohibición de reelección inmediata por dos períodos (Panamá), hasta la reelección inmediata por un solo período.

La verdad es que es muy difícil pensar que en Latinoamérica un Presidente en el poder pueda perder su reelección. De hecho prácticamente en casi todos los países donde se ha introducido la reelección inmediata (por un período), los presidentes en ejercicio han ganado su reelección. En estos países, con excepción de un caso en República Dominicana en el 2004 (M ejía) y Nicaragua en 1990 (Ortega), los Presidentes siempre han resultado reelectos en Colombia (Uribe); Brasil (Cardozo y Lula); Argentina (Menem); Venezuela (Chávez) y Perú (Fujimori). La reelección de presidentes en varios de estos países ha estado acompañada de señalamientos de ventajismos a favor de los presidentes en ejercicio que asumieron simultáneamente la condición de candidatos. Las experiencias venezolanas en los años 2000 y 2006 ponen en evidencia el uso y abuso de los bienes y potestades presidenciales para favorecer al presidente-candidato.

Caso diferente es la elección en Europa de los presidentes en algunos sistemas semi parlamentarios o semi presidenciales, como es caso de Francia. No obstante, el sistema francés es completamente distinto: el primer ministro comparte la jefatura del gobierno con el Presidente y puede ser destituido en cualquier momento por la mayoría parlamentaria (al igual que lo pueden ser los primeros ministros en los regímenes parlamentarios). Se trata de sistemas de gobierno distintos, con controles diferentes. Además, en Francia el período presidencial fue reducido en el año 2000 de 7 a 5 años; y el presidente electo en el año 2007, Nicolas Sarkozy, ha declarado que sería importante limitar la reelección de los presidentes en su país, para evitar que en lugar de dedicarse a ver cómo permanecen en el poder, se dediquen a resolver los problemas de la gente. 
1. Decretar Regiones Especiales Militares en cualquier parte del territorio y en los demás espacios geográficos de la República (PRC, art. 11).

2. Decretar Autoridades Especiales en situaciones de contingencia, desastres naturales, etc. (PRC, art. 11).

3. Crear por decreto Provincias Federales, Ciudades Federales y Distritos Funcionales, así como cualquier otra entidad que establezca la Ley (previo acuerdo aprobado por la mayoría simple de la A samblea Nacional) (PRC, arts. 16 y 236 num. 3).

4. Designar las autoridades de las Provincias Federales. Territorios Federales y/o Ciudades Federales (PRC, arts. 16 y 236 num.3).

5. Fijar el número, organización y competencias de las Vicepresidencias (PRC, art. 236, num. 21).

6. Nombrar a los Vicepresidentes que considere necesarios y removerlos (PRC, arts. 225 y 236 num. 4).

7. Presidir el Consejo Nacional de Gobierno y decidir a quienes de sus integrantes convoca (Vicepresidentes, M inistros, Gobernadores y Alcaldes) (PRC, art. 185).

8. Presidir el Consejo de Estado y determinar las demás personas que considere necesario convocar (además de las autoridades que señala la Constitución) (PRC, art. 252).

9. Ejercer la Suprema Autoridad Jerárquica en todos los Cuerpos, Componentes y Unidades de Fuerza Armada Bolivariana, determinando su contingente (PRC, art. 236 num. 6).

10. Promover a los oficiales de la Fuerza A rmada Bolivariana en todos los grados y jerarquías, y designarlos para los cargos correspondientes (PRC, art. 236 num.7).

11. Destinar la Guardia Nacional para formar cuerpos policiales con una parte de sus recursos humanos, técnicos y materiales (Disposición transitoria).

12. Destinar la Guardia Nacional para conformar cuerpos de tierra, mar y aire, como parte integrante de otros componentes militares (Disposición transitoria).

13. Formular directamente el Plan Nacional de Desarrollo (sin la aprobación de la A samblea Nacional) (PRC, art. 236 num.19).

14. Establecer y regular la política monetaria (PRC, art. 236 num.12). El Ejecutivo Nacional y el Banco Central de Venezuela, fijarán en coordinación las políticas monetarias y ejercerán las competencias monetarias del Poder Nacional (PRC, art. 318).

15. Administrar y dirigir las reservas internacionales de la República (PRC, art. 318).

Estas competencias iban seguidas de una disminución de los controles de otros poderes sobre ellas, debilitando con ello el equilibrio propio de una separación de poderes democrática y afectando con ello al sistema democrático.

\section{F. El fraude constitucional de la "reforma"}

La magnitud de los cambios constitucionales propuestos en la denominada "Reforma Constitucional", representaban una transformación de nuestro Estado, a tal punto que desdibujaba sustancialmente el contenido de la Constitución de 1999, con lo que se estaba cometiendo un "fraude Constitucional". ${ }^{144}$ Esta doctrina sobre el "fraude

\footnotetext{
$\overline{{ }^{144} \text { En ese sentido, ya Pedro De Vega ha señalado que uno de los mayores juristas del siglo XX (M. }}$
} 
constitucional" había sido inocentemente recogida un año antes (2006) por la Sala Constitucional del Tribunal Supremo de Justicia. ${ }^{145}$

En tal virtud, esa normativa no podía ser el resultado del procedimiento para la aprobación de "reformas constitucionales" contemplado en los artículos 342 al 346 de la Constitución; pero aun más: tampoco podía serlo ni siquiera como resultado de una A samblea Nacional Constituyente, ya que contenía diversas normas que configuraban una disminución o regresión en materia de derechos humanos.

\section{G. Los recursos de inconstitucionalidad contra la reforma y la renuncia al control constitucional}

La Reforma Constitucional fue aprobada por la A samblea Nacional el 2 de noviembre de 2007 y ese mismo día, luego de ser remitida al Consejo Nacional Electoral (CNE), este último, en cuestión de horas convocó formalmente al referendo sobre su aprobación a celebrarse en un plazo de treinta (30) días, ello es, el 2 de diciembre de ese año. ${ }^{146}$

En virtud de esa formalización de la aprobación parlamentaria y la convocatoria al referendo por el ente comicial, diversas organizaciones, instituciones y personas acudieron a la Sala Constitucional del Tribunal Supremo de Justicia a demandar la inconstitucionalidad previa de ambos actos: tanto la Reforma Constitucional aprobada por la

Hauriou), había acuñado la expresión "Superlegalidad constitucional" para designar "aquellos preceptos de los de los textos constitucionales en lo que se condensaban los principios y valores legitimadores de toda la legalidad constitucional y que lógicamente no podían ser objeto de reforma constitucional. De suerte que los nomoi que A ristóteles dejó sin definir, ha sido el gran jurista francés, quien ha intentado encerrarlos en esa superlegalidad constitucional, que no podrá ser lesionada nunca y deberá quedar inmune a la acción de la reforma. Es desde ella, desde donde habría que explicar el significado jurídico y, sobre todo, político de las llamadas en los modernos ordenamientos constitucionales, cláusulas de intangibilidad". DE VEGA, Pedro. "La reforma constitucional como defensa de la Constitución y de la democracia", en Revista Peruana de Derecho Público, № 13, Lima, 2006, p. 50. Ver también sobre este tema: RAmírEz CLeves Gonzalo. Los límites a la reforma constitucional y las garantíaslímites del poder constituyente: los derechos fundamentales como paradigma. Universidad Externado de Colombia. Temas de Derecho Público № 69. Bogotá 2003. Se trataba de la violación de esas cláusulas intangibles de la "superlegalidad constitucional" mediante una reforma constitucional conduce al fenómeno que Pedro De Vega denominó fraude constitucional, el cual consiste precisamente en "Ia utilización del procedimiento de reforma para, sin romper con el sistema de legalidad establecido, proceder a la creación de un nuevo régimen político y un ordenamiento constitucional diferente. Su referencia es importante, porque ilustra con extraordinaria plasticidad sobre el significado, el valor y hasta la necesidad de reconocer límites implícitos materiales en cualquier operación de revisión del texto constitucional". DE VEGA, Pedro, La Reforma Constitucional y la problemática del Poder Constituyente, Madrid, 1991, pp. 291 a 293.

145 Sentencia de fecha 25 de enero de 2006. Caso Jesús M anuel Méndez Q uijada y Henry Ramos Allup vs. Consejo Nacional Electoral (Exp. 2005-001786).

${ }^{146}$ No disponemos del tiempo ni del espacio necesario para referirnos en detalle a todos y cada uno de los artículos que integraron la "Reforma Constitucional", lo cual nos obligó a limitarnos a exponer solamente aquellos que consideramos más graves. El texto completo de la reforma puede ser consultado en: www.asambleanacional.gov.ve 
Asamblea Nacional como la resolución de convocatoria al referendo emitida por el Consejo Nacional Electoral, ambos actos de fecha 2 de noviembre de 2007.147

De allí que, el ejercicio del control constitucional por parte de la Sala Constitucional era imprescindible en esos momentos, a fin de verificar si la "Reforma" planteada se ajusta a los límites que la propia Constitución le ha impuesto al Poder Constituido (en especial, la Asamblea Nacional). Con relación al aspecto concreto sometido a la Sala Constitucional, relativo al control de la constitucionalidad de las reformas a la Constitución, es importante destacar la labor de los tribunales constitucionales. ${ }^{148}$

Finalmente, es importante resaltar, que en ese caso la naturaleza jurídica del "referendo constitucional" requerido para la aprobación final de la reforma no era la del ejercicio del poder constituyente por parte del pueblo. Se trataba de una reforma que había sido propuesta por el poder constituido (Presidente de la República) y que había sido sancionada también por el poder constituido (A samblea Nacional). Por lo cual, en estos casos, el referendo constitucional "es, ante todo, una institución de control y garantía", ya que "lo que se pretende es evitar que el poder de revisión, que es un

147 Carlos Ayala y Jesús M aría Casal participaron como accionantes y abogados en el recurso de inconstitucionalidad interpuesto ante la Sala Constitucional del Tribunal Supremo de Justicia de Venezuela el día 15-11-07 (Expediente № 07-1672) por personas y organizaciones no gubernamentales de derechos humanos. En este particular es importante destacar que la impugnación abierta de esa pretendida Reforma Constitucional era posible llevarla a cabo en Venezuela mediante una acción o recurso de inconstitucionalidad como un acto normativo general, en virtud de la caracterización de la acción de inconstitucionalidad como una acción popular desde el siglo XIX. De conformidad con lo previsto en el noveno aparte del artículo 19 de la Ley Orgánica del Tribunal Supremo de Justicia, la legitimación activa en el caso de demandas de nulidad de leyes o actos de efectos generales -y una "Reforma Constitucional" es, sin duda, un acto de efectos generales- la tienen aquellas personas que sean afectadas en sus derechos o intereses por el acto normativo impugnado. El noveno aparte del artículo 21 del texto orgánico que rige las funciones de ese Máximo Juzgado dispone lo siguiente:

(... ) Toda persona natural o jurídica, que sea afectada en sus derechos o intereses por una ley, reglamento, ordenanza u otro acto administrativo de efectos generales emanado de alguno de los órganos del Poder Público Nacional, Estadal o Municipal, o que tengan interés personal, legítimo y directo en impugnar un acto administrativo de efectos particulares, puede demandar la nulidad del mismo ante el Tribunal Supremo de Justicia, por razones de inconstitucionalidad o de ilegalidad. El Fiscal General de la República y demás funcionarios a quienes las leyes les atribuyen tal facultad, podrán también solicitar la nulidad del acto, cuando éste afecte un interés general (...). (Resaltados nuestros).

148 A sí, en A lemania, la jurisprudencia de la Corte Constitucional convirtió la cláusula de intocabilidad de la Ley Fundamental en una base para un control bastante extenso de actos reformatorios de la Constitución, al establecer que tanto el poder constituyente original, como el poder reformatorio "no pueden desconocer exigencias elementales de justicia", en particular la prohibición de la arbitrariedad. En esta jurisprudencia abre el camino precisamente para la interpretación de la constitucionalidad de las leyes reformatorias de conformidad con la Constitución y a la luz de su núcleo intocable. Ver, sentencia de la Corte Federal Constitucional de Alemania, colección de decisiones, t.84.90 121, citada por HeRDEGEN, Mathias. "La Reforma Constitucional: criterios de justiciabilidad", en Anuario de Derecho Constitucional Latinoamericano. 2006, p. 135. En el mismo sentido, la Corte Constitucional de Colombia ha sostenido que el poder de reforma de la Constitución está sometido a "limites constitucionales" que resultan de la "integridad" de la Constitución, es decir, de su esencia como ente consiste. Ver, Corte Constitucional, sentencia C-551 del 9 de julio de 2003, citado por HeRDEGEN, Mathias. "La Reforma Constitucional...", op. cit., p. 136. 
poder constituido y limitado, asuma las funciones y competencias que sólo pertenecen al poder constituyente". ${ }^{149}$ (Resaltados añadidos.)

Como lo ha expresado el mismo autor (citado como autoridad académica en sentencias de la Sala Constitucional del Tribunal Supremo de Justicia ${ }^{150}$ ), con una contundente e inequívoca claridad, que una Reforma Constitucional que viole la Constitución no puede ser sometida a referendo, porque ello "constituiría sencillamente un disparate que, por no admitir el planteamiento de la inconstitucionalidad formal, hubiera que reconocer y dar por buena la posibilidad de que se aprobasen y se presentasen conscientemente a la consulta popular proyectos de reforma claramente inconstitucionales". ${ }^{151}$ (Resaltados añadidos.)

A pesar de lo sólido de los argumentos antes expuestos y contenidos entre los fundamentos de los diversos recursos de inconstitucionalidad ejercidos contra la Reforma Constitucional, ellos fueron rechazados por la Sala Constitucional, utilizando un término que ni es castellano ni es jurídico: "improponible", como para querer decir que el recurso ni siquiera se podía proponer ante el Tribunal, en virtud de que dicha Reforma Constitucional impugnada, 152

"carece de la entidad suficiente para ser impugnada, hasta tanto se verifiquen los efectos definitivos del procedimiento previo a la consulta popular a celebrarse el venidero 2 de diciembre de 2007, una vez aprobadas o no las normas constitucionales propuestas, en caso de subsistir el interés jurídico de cualquier ciudadano en su impugnación podrían ser objeto de un eventual control por parte de esta Sala. En consecuencia, se declara improponible en derecho la solicitud de nulidad en los términos planteados por los actores, y así se decide". (Resaltados y cursiva añadidos).

La Reforma Constitucional inconstitucional fue así y sin ningún obstáculo sometida a referendo popular el día 2 de diciembre de 2007. La campaña a favor y en contra de la propuesta fue muy intensa. Por el oficialismo hubo una inmensa campaña, desproporcionadamente ostensible y más rica en recursos: intervino directamente el Presidente Chávez, movilizando con el apoyo de recursos públicos a sus partidarios y seguidores, ministerios y edificios públicos fueron literalmente empapelados a favor de la reforma, en sus edificios y auditorios se celebraban foros pero solamente a favor de la Reforma con la intervención de ministros, gobernadores y alcaldes oficialistas, los funcionarios públicos eran llevados a las concentraciones a favor de la aprobación de la Reforma; y

149 De VegA, Pedro. La Reforma Constitucional..., op. cit., p. 303.

150 Vgr. en Sentencia de la Sala Constitucional, de fecha 25 de enero de 2006. Caso "Jesús Manuel Méndez Quijada y Henry Ramos Allup vs. Consejo Nacional Electoral".

151 De VegA, Pedro. La Reforma Constitucional..., op. cit., p. 303.

152 Sentencia de fecha 17 de noviembre de 2007, Sala Constitucional del Tribunal Supremo de Justicia, en el caso ACCIÓN SOLIDARIA CONTRA EL SIDA (ACCSI) y otros, (Expediente No 07-1672). Estas sentencias cuentan con dos votos salvados de los magistrados Pedro Rafael Rondón Haaz y Jesús Eduardo Cabrera Romero. Las sentencias y los votos salvados del Tribunal Supremo de Justicia pueden ser consultadas por vía digital en el siguiente portal oficial: www.tsj.gov.ve 
como si todo ello fuera poco, el eslogan oficial de la campaña y el mensaje del propio Presidente Chávez convirtió al referendo en un plebiscito: "Sí por Chávez".

Por el lado de la oposición a la propuesta se movilizó fundamentalmente la sociedad civil y en un segundo plano los partidos de oposición. En esta movilización ciudadana resaltaron particularmente los estudiantes como una fuerza definitiva de concientización y aglutinamiento de la ciudadanía. Esta campaña incluyó una serie de iniciativas espontáneas de sectores sociales mediante foros, publicaciones explicativas, discusiones en sectores populares, elaboración de micros explicativos y otros.

Diversas organizaciones y organismos internacionales manifestaron su preocupación ante el contenido de ciertos aspectos de la Reforma Constitucional sometida a aprobación, entre otros el Centro Carter, Reporteros Sin Fronteras y el Foro por la Vida. Pero es de destacar, incluso por lo inusual, el pronunciamiento hecho por tres relatores de las Naciones Unidas: sobre libertad de opinión y expresión, Ambey Ligabo; sobre defensores de derechos humanos, Hina Jilani; y sobre independencia de jueces y abogados, Leandro Despouy, quienes: ${ }^{153}$

(... ) subrayaron los problemas de seguridad que afrontan quienes participan en manifestaciones públicas contrarias a esa reforma. O pinaron que las nuevas provisiones que quitan autoridad a la Corte Suprema para supervisar y aprobar las declaraciones del estado de emergencia, así como la abolición de los límites de tiempo para imponerlo socavan las libertades civiles de los venezolanos.

Añadieron que otras disposiciones de la reforma limitan algunos derechos fundamentales que deben ser respetados siempre, como la libertad de expresión y el de acceso a la información, piedras angulares de las sociedades democráticas.

También se manifestaron preocupados por las normas que establecen que las asociaciones políticas sólo pueden acceder a fondos nacionales, porque piensan que se podrían aplicar selectivamente a organizaciones de derechos humanos e impedirles recibir fondos del exterior.

Los relatores consideraron que la reforma podría afectar la independencia del poder judicial, porque propone que la destitución de los jueces de la Corte Suprema sea decidida por simple mayoría de votos en la Asamblea Nacional, en lugar de los dos tercios que establece la actual Constitución.

Finalmente, el 2 de diciembre de 2007 se llevó a cabo el referendo sobre la aprobación de la Reforma Constitucional. A pesar de que las autoridades del Consejo Na-

153 Servicio de Noticias de las Naciones Unidas. Nota de prensa de fecha 30 de noviembre, 2007:"Tres relatores de las Naciones Unidas expresaron hoy preocupación por algunas disposiciones de la reforma constitucional venezolana que será sometida a referendo el próximo domingo.". 
cional Electoral habían asegurado en días anteriores que los resultados serían dados oficialmente dentro de las cuatro horas siguientes a haberse cerrado las mesas de la consulta popular, no fue sino hasta la madrugada, pasadas las 2 de la mañana del día siguiente, cuando se emitió el primer boletín oficial, mediante el cual se reconoció la tendencia "irreversible" del "NO" sobre el "SÍ":

PREGUNTA: ¿Aprueba usted el proyecto de Reforma Constitucional con sus Títulos, Capítulos, Disposiciones Transitorias, Derogatoria y Final, presentado en dos bloques y sancionado por la Asamblea Nacional, con la participación del pueblo y con base en la iniciativa del Presidente Hugo Chávez?

BLOQUE A: ARTÍCULOS: 11, 16, 18, 64, 67, 70, 87, 90, 98, 100, 103, 112, 113, $115,136,141,152,153,156,157,158,167,168,184,185,225,230,236,251,252$, 272, 299, 300, 301, 302, 303, 305, 307, 318, 320, 321, 328, 329, 341, 342 у 348.

$\begin{array}{lcc}\text { Opción } & \text { Votos } & \text { Porcentaje } \\ \text { Sil } & 4.379 .392 & 49,29 \% \\ \text { NO } & 4.504 .354 & 50,7 \%\end{array}$

BLOQUE B: ARTÍCULOS: 21, 71, 72, 73, 74, 82, 109, 163, 164, 173, 176, 191, 264, 265, 266, 279, 289, 293, 295, 296, 337, 338, 339.

\section{Opción \\ Sí}

NO

\section{Votos}

4.335 .136

4.522 .332
Porcentaje
$48,94 \%$
$51,05 \%$

Estos resultados corresponden al Porcentaje de Actas de Escrutinios recibidas al momento del Primer Boletín Oficial, como se dijo, en fecha 3 de diciembre de 2007.

Es importante destacar que este resultado "parcial" es el único resultado oficial que está reflejado oficialmente en la página web del Consejo Nacional Electoral, incluso al mes de mayo de 2008: www.cne.gov.ve. El Consejo Nacional Electoral aún no había emanado un Boletín Definitivo con los resultados oficiales, a pesar de que la Ley Orgánica del Poder Electoral en su artículo 33 numeral 10 establece la obligación de publicar los resultados de to das las elecciones y referendos "en la Gaceta Electoral de la República Bolivariana de Venezuela, dentro de los treinta (30) días siguientes a la celebración de las elecciones."

\section{ALGUNAS AMENAZAS}

A continuación, mencionaremos una serie de amenazas a la democracia constitucional venezolana:

a. La falta de separación de poderes y de independencia del poder judicial;

b. La consecuente disminución de los índices de tutela judicial, particularmente frente a la administración pública; 
c. La ausencia de controles efectivos por parte de los otros órganos del poder público (A samblea Nacional, Defensoría del Pueblo, Contraloría General de la República, y el Ministerio Público),

d. La personalización del poder: la desaparición paulatina de las fronteras entre el Estado y el Gobierno, y entre éstos y el proyecto político de la revolución bolivariana;

e. La consecuente utilización de los recursos públicos (medios de comunicación, instalaciones públicas, recursos financieros, etc.) para financiar el partido oficial;

f. Intolerancia y discriminación contra la sociedad civil y los grupos de derechos humanos (la “Lista Tascón");

g. La utilización de las facultades administrativas del Contralor General de la República para "inhabilitar políticamente" a candidatos de la oposición con opciones de triunfo;

h. La utilización de los decretos leyes para imponer aspectos importantes de la reforma constitucional que fueron rechazados;

i. Las amenazas sobre la enseñanza privada; la empresa privada y las inversiones, a través de la "estatización estratégica" de sectores.

\section{BIBLIOGRA FÍA}

Ayala Corao, Carlos y otros (1983): “Presentación” en Reformas al Presidencialismo en A mérica Latina, (Caracas, Comisión Andina de Juristas y Editorial Jurídica Venezolana). A yala Corao, Carlos (2004): El referendo revocatorio (Caracas, Ediciones El Nacional). Ayala Corao, Carlos (2008): “De la Constituyente de 1999 a la Reforma Constitucional de 2007", en libro sobre Los Procesos Constituyentes En A mérica Latina (México, UNAM).

Brewer-Carías, Allan (2007): Estudios Sobre el Estado Constitucional (2005-2006), (Caracas, Editorial Jurídica Venezolana).

Brewer-Carías, Allan (1999): Debate Constituyente (A portes a la Asamblea Nacional Constituyente), Tomos I, II y III (Caracas, Editorial Jurídica Venezolana).

Brewer-Carías, Allan (2004): La Constitución de 1999. Derecho Constitucional Venezolano. Tomos I y II. (Caracas).

Brewer-Carías, Allan (2000): El sistema de justicia constitucional en la Constitución de 1999, (Caracas, Editorial Jurídica Venezolana).

Brewer-Carías, Allan (2007): La Reforma Constitucional de 2007 (Comentarios al Proyecto inconstitucionalmente sancionado por la A samblea Nacional el 2 de noviembre de 2007). Colección textos legislativos, (№ 43), (Caracas, Editorial Jurídica Venezolana).

Bruni Celli, M arco Tulio: “Los partidos políticos y la Democracia en Venezuela”, disponible en página Web: http:// www.ucab.edu.ve/clubderomaVenezuela/ LIBROCDE/ MTBRUNIC.DOC

Canova, A ntonio (2000): “La Futura justicia constitucional en Venezuela”, en Revista de Derecho Constitucional (№ 2), pp. 104 y ss. 
CASAL H., Jesús M. (2004): Constitución y Justicia Constitucional (Caracas, UCAB).

CASAL H., Jesús M. ( 2005): "Los actuales desafíos de la justicia constitucional en Venezuela", Estado de Derecho, Administración de Justicia y Derechos Humanos, XXX Jornadas J.M. Domínguez Escovar", IEJEL, pp. 287-333.

CASAL H., Jesús M. (2008): Los Derechos Humanos y su protección (Caracas, UCAB)

Chavero, Rafael y otros (2004): La Guerra de las Salas (Caracas).

CopRE (1987): Reformas inmediatas al Poder Judicial. Cuadernos para la Discusión, № 5 (Caracas, Ediciones CO PRE).

CoPRE (1990): Fortalecimiento del Estado de Derecho. Vol. 5 (Caracas, Ediciones COPRE).

DE VeGA, Pedro (2006): "La reforma constitucional como defensa de la Constitución y de la democracia", en Revista Peruana de Derecho Público (№ 13), pp. 50 y 303.

Haro, José Vicente (1999): "La justicia constitucional en Venezuela y la Constitución de 1999", en Revista de Derecho Constitucional (№ 1), pp. 151 y ss.

HeRDEGEN, M athias (2006): "La Reforma Constitucional: criterios de justiciabilidad", en Anuario de Derecho Constitucional Latinoamericano, p. 135.

LALANDER Richard: "Algunas reflexiones sobre populismo, descentralización y chavismo", disponible en página Web: http://www.saber.ula.ve/bitstream/123456789/ 23324/1/richard_lalander.pdf

LóPeZ MaYA, Margarita y M Éndez, Carlos: "Partidos y sistema de partidos en Venezuela". En: "La Política por dentro, cambios y continuidades en las organizaciones políticas de los países andinos", Lima, IDEA, 2007.

Ordóñez Sambrano, Luis y Ordóñez , Luis A.: "Evolución y cambio de los partidos políticos venezolanos", disponible en página Web: http://www2.scielo.org.ve/ scielo.php?script=sci_arttext $\&$ pid=S030397572004000100004\& $\mathrm{lng}=\mathrm{es} \& \mathrm{nrm}=\mathrm{iso}$

PÉREZ, Samuel (1996): Los partidos políticos en Venezuela. Los partidos modernos, II, Cuaderno $\mathrm{N}^{\circ} 36$ del Curso de Formación Sociopolítica (Caracas, Fundación Centro Gumilla).

Pérez Perdomo, Rogelio (1995): Políticas Judiciales en Venezuela (Caracas, Ediciones IESA. Estudios IESA) № 3.

Pérez Perdomo, Rogelio (coord..); Boza, María Eugenia y Nja Im, Humberto (1994): Seguridad Jurídica y Competitividad (Caracas, IESA).

Ramírez Cleves, Gonzalo (2003): Los límites a la reforma constitucional y las garantíaslímites del poder constituyente: los derechos fundamentales como paradigma (Bogotá, Universidad Externado de Colombia). Temas de Derecho Público, № 69.

ReY, Juan Carlos: "Problemas sociopolíticos de A mérica Latina”, Caracas, UCV, Facultad de Ciencias Jurídicas y Políticas, 1998. 